OPEN ACCESS

Edited by:

Tae-Hee Cho,

Hospices Civils de Lyon, France

Reviewed by:

Maxime Gauberti, INSERM, France

Fabien Chauveau,

Lyon Neuroscience Research Center (INSERM), France

${ }^{*}$ Correspondence:

Midori A. Yenari

yenari@alum.mit.edu

Specialty section:

This article was submitted to Stroke, a section of the journal

Frontiers in Neurology

Received: 19 May 2017

Accepted: 23 August 2017 Published: 07 September 2017

Citation:

Mizuma A and Yenari MA (2017) Anti-Inflammatory Targets for the

Treatment of Reperfusion Injury in Stroke.

Front. Neurol. 8:467.

doi: 10.3389/fneur.2017.00467

\section{Anti-Inflammatory Targets for the Treatment of Reperfusion Injury in Stroke}

\begin{abstract}
Atsushi Mizuma and Midori A. Yenari*
Department of Neurology, University of California, San Francisco and Veterans Affairs Medical Center, San Francisco, CA, United States
\end{abstract}

While the mainstay of acute stroke treatment includes revascularization via recombinant tissue plasminogen activator or mechanical thrombectomy, only a minority of stroke patients are eligible for treatment, as delayed treatment can lead to worsened outcome. This worsened outcome at the experimental level has been attributed to an entity known as reperfusion injury (R/l). R/l is occurred when revascularization is delayed after critical brain and vascular injury has occurred, so that when oxygenated blood is restored, ischemic damage is increased, rather than decreased. R/I can increase lesion size and also worsen blood barrier breakdown and lead to brain edema and hemorrhage. A major mechanism underlying $\mathrm{R} / \mathrm{l}$ is that of poststroke inflammation. The poststroke immune response consists of the aberrant activation of glial cell, infiltration of peripheral leukocytes, and the release of damage-associated molecular pattern (DAMP) molecules elaborated by ischemic cells of the brain. Inflammatory mediators involved in this response include cytokines, chemokines, adhesion molecules, and several immune molecule effectors such as matrix metalloproteinases-9, inducible nitric oxide synthase, nitric oxide, and reactive oxygen species. Several experimental studies over the years have characterized these molecules and have shown that their inhibition improves neurological outcome. Yet, numerous clinical studies failed to demonstrate any positive outcomes in stroke patients. However, many of these clinical trials were carried out before the routine use of revascularization therapies. In this review, we cover mechanisms of inflammation involved in R/I, therapeutic targets, and relevant experimental and clinical studies, which might stimulate renewed interest in designing clinical trials to specifically target $\mathrm{R} / \mathrm{l}$. We propose that by targeting anti-inflammatory targets in R/I as a combined therapy, it may be possible to further improve outcomes from pharmacological thrombolysis or mechanical thrombectomy.

Keywords: reperfusion injury, postischemic inflammation, microglia, hyperglycemia, ischemic stroke, revascularization, tissue plasminogen activator, endovascular treatment

\section{INTRODUCTION}

Treatment of acute ischemic stroke has largely been limited to strategies to restore blood flow. Pharmacological recanalization, particularly tissue plasminogen activator (tPA) has been the mainstay for acute treatment for the past 20 years $(1,2)$, but in recent years, several studies have shown that mechanical embolectomy is also effective (3). However, the short time frame for safe 
intervention is still limited even considering recent studies that suggest additional criteria for treating "wake up stroke" (4) and longer time windows of up to $24 \mathrm{~h}$ for embolectomy (5). It is still estimated that less than $10 \%$ of all acute stroke patients benefit from reperfusion strategies. One of the reasons for such a short time window is that intervention beyond this time window actually increases risk and leads to worsened outcome (6). If these recanalization therapies are applied too late, there is an increased risk of cerebral hemorrhage, which can sometimes prove fatal (7). The mechanism of cerebral hemorrhage complicating ischemic stroke is a consequence of a phenomenon known as "reperfusion injury" (R/I) (8) to which inflammation is a major contributing cause.

While the restoration of cerebral blood flow $(\mathrm{CBF})$ is a major goal of acute stroke treatment, it can also lead to more extensive brain tissue damage in the adjacent penumbral territory (9). If recanalization is carried out after a critical time window, the sudden restoration of oxygenated blood into ischemically compromised brain tissue may overwhelm already compromised endogenous antioxidant systems and damaged vascular endothelia leading to brain edema and extravasation of blood cells. The generation of reactive oxygen species (ROS) from compromised mitochondria not only leads to direct cellular damage but also can trigger the activation of both the peripheral (leukocytes) and brain resident (microglia) immune pathways, which in turn, elaborate various damaging immune mediators and effectors including more ROS. This vicious cycle in acute ischemic stroke is referred to as cerebral R/I (Figure 1) $(10,11)$.

The evidence for $\mathrm{R} / \mathrm{I}$ was previously demonstrated using experimental stroke models. A few groups have reported that ischemic injury is greater in animals where reperfusion occurs [temporary middle cerebral artery occlusion (tMCAO) for $2-3 \mathrm{~h}$ ] compared to animals where there is no reperfusion (pMCAO) $(12,13)$. In a series of experiments where the duration of MCAO was varied and compared to pMCAO, tMCAO for less than $2 \mathrm{~h}$ led to smaller infarct sizes compared to pMCAO (14). Occlusion durations of more than $2 \mathrm{~h}$ led to paradoxically larger infarct volumes. However, direct evidence for $\mathrm{R} / \mathrm{I}$ is less clear at the clinical level. While a rare "hyperperfusion syndrome" of accelerated brain edema and transient clinical worsening following abrupt revascularization has been described (15), it is not clear whether this results in permanent worsened outcome. Further, the neurotoxicity of IPA has been shown in previous studies, where endogenous tPA may directly contribute to worsened outcome (16). Further, it is quite clear that revascularization after certain time windows can worsen outcomes compared to no intervention (6) and could be said to represent R/I in humans. Hence, targeting aspects of R/I might suggest an opportunity to synergistically improve neurological outcome for thrombolysis and/or mechanical embolectomy.

While the concept of R/I as a therapeutic target surrounding revascularization, the efficacy of treatment in experimental reperfusion models does not necessarily predict the results of clinical trials. A PubMed search for experimental studies covering the terms "reperfusion injury, cerebral ischemia, and inflammation" revealed that 888 studies have been performed using the tMCAO model. However, only one agent (edaravone) has actually been transition to the clinical level in Japan. Experimental reperfusion models do not fully replicate what happens in clinical stroke. Hence some reports argue that experimental reperfusion models were inappropriate for clinical translation (17). Regardless, the timing of treatment is different for each clinical case. These factors are major problems that cannot be avoided. However, some novel mechanisms associated with $\mathrm{R} / \mathrm{I}$ have been established in over the years by studying experimental models and may suggest therapeutic targets which could be studied at the clinical level in this new era of recanalization.

In this review, we will focus on the mechanism of $\mathrm{R} / \mathrm{I}$ in acute ischemic stroke and reconsider its treatment, with a focus on proinflammatory targets, including some already in use at the clinical level.

\section{INFLAMMATION IN STROKE}

The poststroke inflammatory response consists of aberrant activation of glial cells, particularly microglia, and the infiltration of peripheral leukocytes, following exposure to molecules containing damage-associated molecular patterns (DAMPs) released by ischemic brain cells (Figure 1) (18-22). DAMPs studied in brain ischemia include HMGB-1, purines, nucleotides such as ATP and UDP, and nucleic acid fragments (15). DAMPs stimulate immune cell production of cytokines/chemokines, adhesion molecules, and several immune molecule effectors such as matrix metalloproteinases-9 (MMP-9), inducible nitric oxide synthase (iNOS), nitric oxide (NO), ROS, and nicotinamide adenine dinucleotide phosphate (NADPH) oxidase, all of which lead to exacerbation of cerebral ischemic injury $(18,20,21)$.

\section{Microglial/Macrophage Activation}

Microglia are the brain's resident immune cell (23) and are involved in the modulation of the brain's inflammatory response. Circulating monocytes are also recruited from bloodstream and enter brain as macrophage and associated with inflammation (24). Once injury occurs, microglia and macrophage are activated and release proinflammatory molecules such as cytokines [e.g., tumor necrosis factor- $\alpha$ (TNF- $\alpha)$, interleukin-1 $\beta$ [IL-1 $\beta$ ], IL-6, and interferon- $\gamma($ IFN- $\gamma)$ ], chemokines, NO, ROS, MMP-9, glutamate, and ATP (25-32). Microglia are immediately activated following ischemia, elaborating various immune molecules which set the stage for the recruitment of circulating leukocytes (27). Activated microglia affects to neuroinflammation as macrophage-like cells (33). Macrophages also enter the brain from the circulation as early as $24 \mathrm{~h}$ after stroke onset. Their numbers in ischemic lesions peak within 3-7 days (34) but remain within the lesion for weeks to even months (35-39). Phagocytic microglia or infiltrated circulating macrophages are thought to remove necrotic debris and other potentially damaging substances, paving the way for recovery and repair (40).

Interestingly, while activated microglia/macrophage have been thought to worsen damage in stroke, they also appear to contribute to their protection $(35,41-44)$. Recent work has now shown that activated microglia/macrophage can be classified into two broad subpopulations-M1 and M2, with the former being proinflammatory and the latter being anti-inflammatory $(33,45)$. Acutely, microglia appear to polarize predominantly to a M1 


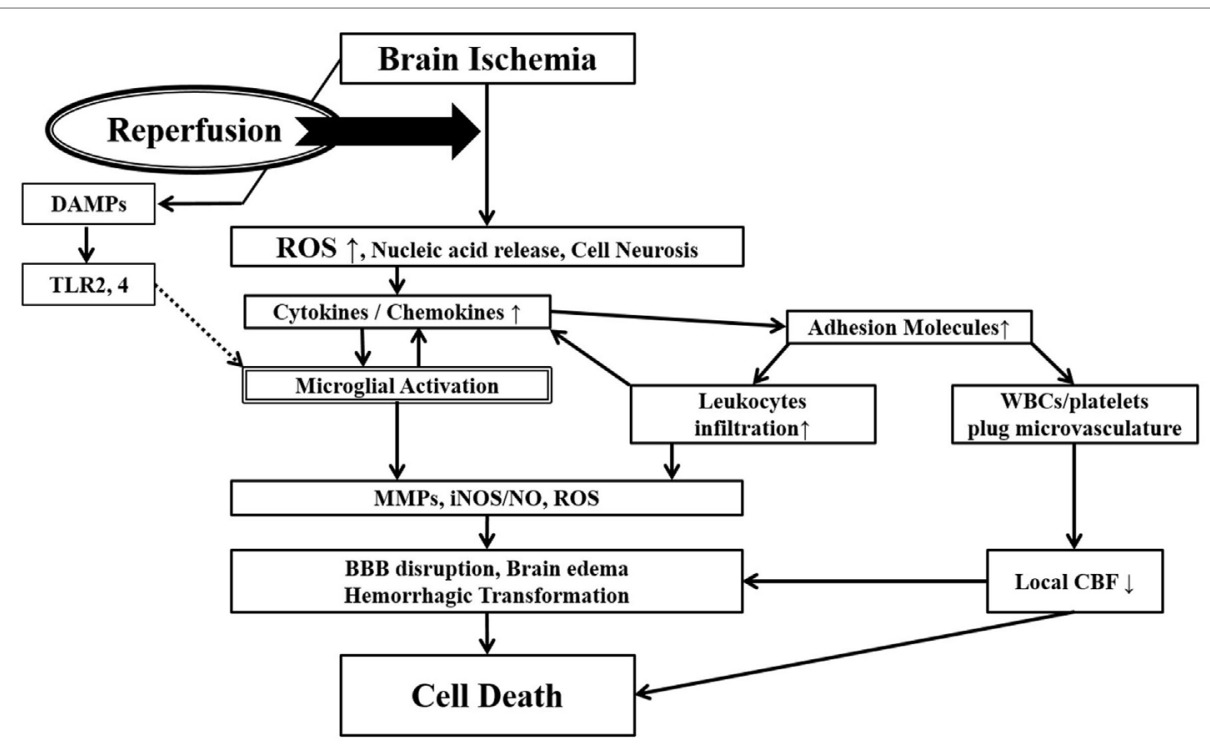

FIGURE 1 | Ischemia-induced inflammation in association with reperfusion injury. Once brain ischemia occurs, oxygen and glucose supplies are reduced. If ischemia occurs for more than a certain time period (likely a few hours, but the precise duration is not well established) and blood flow is restored (reperfusion), worsened injury can paradoxically occur to the brain. This is often referred to as reperfusion injury. A major component of reperfusion injury involves subsequent inflammatory reactions induced through various mechanisms. Reperfusion leads to the introduction of ROS from oxygenated blood and can stimulate an immune response in the ischemic brain. Necrotic, ischemia-injured cells lyse and release their contents into the extracelluar space which can act as ligands for various immune receptors. Among these include nucleic acids which are one of many described damage-associated molecular pattern (DAMPs, see text for details). DAMPs can then bind TLRs and stimulate several inflammatory responses (microglial activation, overexpression of proinflammatory cytokines, chemokines) which lead to worsened brain injury. Inflammatory signaling also causes immune cells to generate more effector molecules such as ROS and iNOS/NO. In the periphery, cytokines and adhesion molecules can attract circulating immune cells to the ischemic brain where they infiltrate the damaged tissue and further amplify ischemic injury. Some circulating immune cells and platelets can also plug the microvasculature of the ischemic brain and cause secondary reductions in local CBF. In addition to brain cells, these inflammatory reactions can also cause damage to brain endothelia causing BBB disruption, edema and hemorrhagic transformation. Thus, the restoration of CBF can cause more extensive brain tissue damage. This vicious cycle is often called reperfusion injury. ROS, reactive oxygen species; DAMPs, damage-associated molecular patterns; TLR, toll-like receptor; MMPs, matrix metalloproteinases; iNOS, inducible nitric oxide synthase; NO, nitric oxide; BBB, blood-brain barrier; CBF, cerebral blood flow.

phenotype and produce cytokines, ROS, and reactive nitrogen species (45). As such, iNOS is the major NOS in immune cells that leads to NO generation, and is often used as a M1 marker (46). The M1 phenotype is mainly associated with proinflammatory signaling (47). In contrast, the M2 phenotype contributes to anti-inflammatory responses as well as recovery and repair (45). Cytokines associated with the M2 phenotype include IL-4, IL-10, IL-13, IGF-1, and transforming growth factor (TGF)- $\beta$ $(33,45,48)$. These cytokines are also important for protection from inflammation $(33,48-53)$. Arginase 1 , which competes with iNOS and downregulates NO production, is often used as a marker for M2 activation (54).

Several innate immune receptors have been studied in relation to activated microglia and the inflammatory cascade. These receptors have in common their ability to activate when stimulated by DAMPs. Purinergic receptors, especially $\mathrm{P}_{2} \mathrm{X}_{7}$ and $\mathrm{P} 2 \mathrm{Y}_{12}$, were previously reported to modulate microglial activation and mediate neurotoxicity (55). Similarly, pharmacologic inhibition of $\mathrm{P}_{2} \mathrm{X}_{7}$ and $\mathrm{P}_{2} \mathrm{Y}_{12}$ reduced brain injury in experimental stroke models (55). Other innate immune receptors studied in stroke include toll-like receptors (TLRs), transient receptor potential melastatin 2, CD36 scavenger receptors, and receptor for advanced glycosylation endproducts (RAGE) (56-60).

\section{Astrocyte}

Astrocytes also play an important role as the source of various inflammatory molecules (61). Activated astrocytes are sometimes referred to as "reactive gliosis" after ischemia and have been observed 4-24 h after ischemia onset, peaking at around 4 days. This state is accompanied by astrocytic upregulation of glial fibrillary acidic protein. The resulting glial scar is a consequence of reactive cellular processes that consists of activated astrocytes and has an important role which leads to both benefit and harm (62). While this glial scar acts as a barrier surrounding the ischemic lesion, it may also prevent axonal regrowth (63). Further, activated astrocytes are directly associated with inflammatory responses after ischemia through upregulation of major histocompatibility complex and other inflammatory molecules such as cytokines, chemokines and iNOS (61). These molecules can exacerbate ischemic injury. In contrast, activated astrocytes are also capable of developing Th2 (anti-inflammatory) responses, although this mechanism has not been reported in ischemia (64). Further, some astrocyte derived immune molecules have been shown to have contrasting effects in a model of spinal cord injury (65). Thus, the modulation of activated astrocytes may be critical in influencing the role of inflammation in brain ischemia, although this area of investigation is still quite new. 


\section{Leukocyte Infiltration}

There are very few peripheral leukocytes in uninjured brain, but once an ischemic stroke occurs, endothelial cells within the cerebral microvasculature are activated and leukocyte infiltration follows a few hours later $(41,66,67)$. This immune cell activation and infiltration appears to be more robust following tMCAO compared to pMCAO (68). Once infiltrated, leukocytes contribute to the worsening of brain damage through similar mechanisms as activated microglia $(18,35)$. In addition, circulating leukocytes also lead to platelet aggregation through activation of the arachidonic acid cascade (i.e., leukotrienes, thromboxane, and prostaglandins) (69). This aggregation promotes a prothrombotic state and induces a "no-reflow" state which can also further compromise ischemic tissue $(61,70)$. Leukocyte-platelet complexes are formed which causes further damage by plugging the microvasculature. Thus, circulating leukocytes worsen ischemic injury through direct infiltration into the ischemic brain and by obstructing in situ blood flow (61).

\section{Neutrophils}

Neutrophils are the first population of leukocytes to appear in the acute ischemic brain $(71,72)$. While they function as any other effector immune cell, their significance has been debated. Several studies have shown that inhibiting their ability to infiltrate ischemic brain led to smaller lesion sizes (61). However, numbers of neutrophils in the ischemic brain do not appear to predict stroke severity (73-75). Further, this strategy has not been shown to improve outcomes in stroke patients (76). In addition, Enzmann et al. (75) argued that neutrophil infiltration was not present in infarcts at an early stage after ischemia. In this study, platelet aggregation, sites of increased vessel permeability, and sites of enhanced expression of endothelial adhesion molecules were also correlated with neutrophils infiltration. Hence, the role of neutrophils in stroke is still unclear, particularly since clinical studies to inhibit their infiltration were conflicting.

\section{Lymphocytes}

Activated T lymphocytes also appear in ischemic brain tissue as early as $24 \mathrm{~h}$ after reperfusion, but later than neutrophils and before macrophages (77). They act as a modulators of leukocyte and platelet adhesion (78). T lymphocytes also produce inflammatory cytokines such as IL-17 and IFN- $\gamma$. CD4 ${ }^{+}$helper, $\mathrm{CD} 8^{+}$cytotoxic, and $\gamma \delta \mathrm{T}$ cells have been shown to play harmful roles in experimental stroke $(78,79)$. Yilmaz et al. (79) reported that the deficiency of $\mathrm{CD} 4^{+}$helper/CD8 ${ }^{+}$cytotoxic $\mathrm{T}$ cells led to smaller infarct sizes, lower number of adherent leukocytes and lymphocytes, and better neurological outcomes following tMCAO in mice. $\gamma \delta \mathrm{T}$ lymphocytes mainly produce IL-17, and IL-17 seems to play an important role in the delayed phase of R/I (78). Hence, they may be important therapeutic targets. In fact, high levels of IL-17 have been documented in human ischemic lesions (80). IL-23 also appears to mediate IL-17. Shichita et al. (78) showed infarct volume reduction and improvement of neurological functions in IL-17/IL-23 KO mice. However, while the harmful role of T lymphocytes in brain ischemia was demonstrated in a tMCAO model and R/I, the same has not been shown in pMCAO for unclear reasons (81). Further, T regulatory cells
$\left(\mathrm{T}_{\text {regs }}\right)$ seem to play an anti-inflammatory and neuroprotective role in ischemic stroke. $\mathrm{T}_{\text {regs }}$ interact with other cells to release anti-inflammatory cytokines (IL-10 and TGF- $\beta$ ) (24). Liesz et al. (82) reported that the depletion of $\mathrm{T}_{\text {regs }}$ increased infarct volume and worsened of neurological function. Further, anti-CD28 antibody (CD28SA) was shown to reduce infarct volume and improve neurological deficit by increasing numbers of $\mathrm{T}_{\text {regs }}(83)$. In contrast, Kleinschnitz et al. argued that $\mathrm{T}_{\text {regs }}$ could promote IS via cerebral microvasculature dysfunction, as $\mathrm{T}_{\text {regs }}$ depletion was neuroprotective (84). Further, CD28SA contributed to enhanced $\mathrm{T}_{\text {regs }}$ effects by promoting thromboinflammation $\mathrm{T}_{\text {regs }}$ have also been reported to inhibit t-PA induced hemorrhagic transformation (HTf) through regulation of MMP-9 and suggests $\mathrm{T}_{\text {regs }}$ as a potentially important target in preventing this complication in the setting of recombinant tPA use (85). Clearly, $\mathrm{T}_{\text {regs }}$ in acute IS is complex and more investigation is needed. $\mathrm{B}$ lymphocytes also contribute to the reduction of inflammation and neurological deficits through IL-10 release (86).

In clinical studies, the relationship between lymphocyte numbers and poststroke pathology is not clear. Nadareishvili et al. (87) reported that high serum lymphocyte counts increased the risk of stroke recurrence and mortality. In contrast, Kim et al. (88) reported that lower lymphocyte counts were associated with poor early neurologic improvement and worse long-term functional outcome.

\section{Cytokines/Chemokines}

Several cytokines and chemokines are released following ischemic brain injury $(19,20)$. They have been detected in blood, cerebrospinal fluid, and infarcted brain regions in both acute ischemic stroke patients and experimental animals (20). In microglia, distinct molecules are expressed, depending on the cell's phenotype $(23,33)$. M1 microglia generate proinflammatory cytokines, which contribute to the worsening of brain injury (45). The most extensively studied of the proinflammatory cytokines include IL-1, IL-6, and TNF- $\alpha$ (89). Cytokines from M2 phenotype microglia appear to contribute a protective or beneficial effect, and are thought to inhibit inflammation and promote tissue repair $(33,48-53)$. Representative anti-inflammatory cytokines studied in stroke are IL-4, IL- 10 , IL-23, and TGF- $\beta 1(33,45,48)$. Several chemokines have been studied in stroke models and appear to play a variety of roles in cell migration and attraction to sites of damage.

\section{Proinflammatory Cytokines}

Interleukin- 1 is consists of two isoforms IL- $1 \alpha$ and IL- $1 \beta$, which are major contributors of acute inflammation in ischemic stroke and have been studied as therapeutic targets (90). IL-1 also indirectly affects brain injury through initiating astrogliosis, releasing toxic substances [chemokines, vascular cell adhesion molecule (VCAM)-1, and intercellular adhesion molecule (ICAM)-1], and activating metalloprotenase (MMP)-9 (91-93). Both isoforms increase in the first hours of acute ischemic stroke and bind to their corresponding receptors (IL-1R1 and IL-1R2) $(24,61,90)$. Previous studies showed that IL- $1 \beta$ contributed more to ischemic pathology rather than IL-1 $\alpha$ (93). IL-1 $\beta$ mRNA and protein are detected within 1-6 h after ischemia with a biphasic pattern of 
expression that includes a secondary peak 6-24 h later (94). Administration of IL- $1 \beta$ led to the enlargement of infarct size (95), whereas the lack of IL-1 $\beta$ was led to smaller infarct size (93). Similarly, studies have explored the feasibility of administering its endogenous inhibitor, IL-1ra, which seems to improve outcomes in experimental models.

Interleukin- 6 has also been studied in ischemic stroke, but its role has not been clarified. The expression and increase of IL-6 is observed as early as $3 \mathrm{~h}$, peaking at $12 \mathrm{~h}$, and remains elevated at $24 \mathrm{~h}$ after onset of brain ischemia (96). IL-6 has been detected in plasma and cerebrospinal fluid of stroke patients, and IL-6 immunoreactivity has been detected in microglia and cortical neurons of ischemic stroke models (96). In patients, IL-6R polymorphisms are also related to poor neurological outcomes (97), although IL-6 polymorphisms did not show an increased risk of ischemic stroke (98). To add to the conflicting observations, IL-6-deficient mice and mice treated with an IL-6 receptor antagonist mice did not have improved outcomes compared to untreated mice $(99,100)$.

Tumor necrosis factor- $\alpha$ has also been detected in ischemic brain (96) and appears largely in microglia as early as $30 \mathrm{~min}$ after experimental stroke (96). This expression has been observed in a variety of other brain cells including neurons and astrocytes. Interestingly, TNF- $\alpha$ has been reported to be both neurotoxic and neuroprotective in the brain. Yang et al. (101) reported that administration of neutralizing antibodies to TNF- $\alpha$ showed a protective effect against ischemic injury in tMCAO model. In contrast, Bruce et al. (102) reported that ischemic brain injury was increased in mice genetically deficient in the TNF receptor. Reasons for this discrepancy could be explained by its two different surface receptors (TNFR1 and TNFR2) (103). TNF- $\alpha$ exists in transmembrane and soluble forms. Soluble TNF- $\alpha$ binds to TNFR1 leading to neurotoxic effects, whereas membrane bound TNF- $\alpha$ binds to TNFR2 leading to neuroprotective effects (104). However, Pradillo et al. (105) reported that TNFR1 signaling pathways led to resistance to ischemic injury through upregulation of TNF- $\alpha$ convertase enzyme and TNFR1. To confuse matters more, it also appears that the effects of TNF- $\alpha$ induced in striatum are neurodegenerative, whereas that in the hippocampus is neuroprotective (106).

T cell-releasing proinflammatory cytokines are also important in the development of ischemic stroke (77). IFN- $\gamma$, IL-17, and IL-23 have been studied recently as therapeutic targets (78). IL-17 induces TNF- $\alpha$, IL-1 $\beta$, and MMP-9 in macrophages and expression and IL-23 induces the expression of IL-17 $(107,108)$. As such, IL-17 and IL-23 both contribute to the worsening of ischemic injury.

\section{Anti-Inflammatory Cytokines}

Interleukin-10 is an anti-inflammatory cytokine mainly produced by microglia, macrophages, and astrocytes, and has a neuroprotective effect in ischemic injury $(33,61)$. IL-10 acts by inhibiting proinflammatory cytokines, such as IL- $1 \beta$, TNF- $\alpha$, and IFN- $\gamma$, and suppresses the expression and activation of cytokine receptors $(61,82)$. Overexpression or administration of IL-10 has been reported to reduce brain injury and improve neurological outcomes in experimental stroke. Ooboshi et al. (109) reported that postischemic gene transfer of IL-10 into the lateral ventricle reduced brain infarct size. At the clinical level, lower IL-10 levels increased stroke risk (110). $\mathrm{T}_{\text {regs }}$ also produce IL-10 $(24,82)$ and $\mathrm{Li}$ et al. (111) reported that administration of $\mathrm{T}_{\text {regs }}$ reduced immune cell infiltration, brain inflammation, and prevented blood-brain barrier $(\mathrm{BBB})$ disruption.

Transforming growth factor- $\beta 1$ is also produced by microglia, macrophages, and astrocytes after ischemia and has also been shown to protect from ischemic injury (112). Like IL-10, overexpression or administration of TGF- $\beta 1$ reduced ischemic lesion size and improved neurological outcomes in experimental stroke model $(113,114)$.

Interleukin-4 is another widely studied anti-inflammatory cytokine produced by activated Th2 cells, eosinophils, basophils, and mast cells (115). IL-4 signaling is mediated through IL-4 receptor $\alpha$-chain (IL- $4 \mathrm{R} \alpha$ ) on neutrophils, T lymphocytes, astrocytes, oligodendrocytes, and endothelial cells $(116,117)$. After binding, this complex dimerizes with the common $\gamma$-chain or IL-13R $\alpha 1$ which is a closely related cytokine receptor (118). This signaling contributes to potent anti-inflammatory responses in ischemic brain which include upregulating Arg1, Ym1, found in inflammatory zone 1 (FIZZ1), CD206 (mannose receptor), chemokine ligand 22 (CCL22), and CD163, which are also M2 specific markers (117). IL-4 inhibits the release of proinflammatory cytokine genes such as IL- $1 \beta$, TNF- $\alpha$, IL- 6 , and chemokines, and the activation of macrophage mannose receptor (119). IL-4 levels in brain are generally very low, but increase several hours after stroke onset (116). Xiong et al. (51) reported that IL-4 deficiency exacerbated brain injury and worsened neurological outcomes in tMCAO. Further, IL-4 appears to have long-term neuroprotective effects after experimental stroke (116). However, it bears mentioning that other studies reported that IL-4 was associated with proinflammatory responses (120). Pretreatment of monocytes and macrophages with IL- 4 has also been shown to enhance proinflammatory cytokine gene expression such as TNF- $\alpha$, IL1- $\alpha$, and macrophage-inflammatory protein-2 (121).

\section{Chemokines}

Chemokines mediate chemotaxis, including leukocyte migration (122). They also participate in the pathogenesis of cerebral ischemia through their involvement in leukocyte infiltration, ROS release, and BBB disruption $(24,61)$. Based on their structures, chemokines are divided into four subgroups; CXC, CC, C, and $\mathrm{CX}_{3} \mathrm{C}$ (123). Corresponding receptors include CXCR (1-5), CCR (1-9), XCR1, and $\mathrm{CX}_{3} \mathrm{CR} 1$ (61). Both chemokines and their receptors have been explored as potential therapeutic targets $(24,123)$.

Stromal cell-derived factor (SDF)-1 (CXCL12) is a CXC chemokine (124). It is produced by bone marrow stromal cells and acts as a strong chemoattractant for CD34+ cells, which express SDF- $1 \alpha$ receptor (CXCR4) (124). SDF- $1 \alpha / C X C R 4$ signaling plays an important role in ischemia-induced inflammation via activation and migration of leukocytes (125). Ruscher et al. (126) reported that the inhibition of CXCL12 reduced infiltration of immune cells and Huang et al. (127) also confirmed that CXCR4 antagonism led to neurological recovery, suppression of proinflammatory cell infiltration, reduction of infarct area, and $\mathrm{BBB}$ disruption in $\mathrm{TMCAO}$. 
Fractalkine $\left(\mathrm{CX}_{3} \mathrm{CL} 1\right)$ is a $\mathrm{CX}_{3} \mathrm{C}$ chemokine that is mainly expressed on neurons and acts through $\mathrm{CX}_{3} \mathrm{CR} 1$ on microglia (128). Fractalkine bound to $\mathrm{CX}_{3} \mathrm{CR} 1$ leads to expression of proinflammatory cytokines, ROS production, $\mathrm{BBB}$ disruption, and leukocyte infiltration $(24,128)$. However, the role of $\mathrm{CXC}_{3} \mathrm{CL} 1 /$ $\mathrm{CXC}_{3} \mathrm{R} 1$ signaling is still controversial. While Soriano et al. (129) reported that fractalkine deficiency reduced infarct volume and mortality in tMCAO, Cipriani et al. (130) showed that administration of $\mathrm{CX}_{3} \mathrm{CL} 1$ reduced ischemic injury. Reasons for these discrepancies are unclear.

Of the CC chemokines, monocyte chemoattractant protein (MCP)-1 (CCL2) and macrophage inflammatory protein-1 $\alpha$ (CCL-3) have been the most studied and participate in leukocyte infiltration $(24,131)$. CCL2 and CCL3 are mainly expressed on astrocytes, microglia, and monocytes, and CC chemokine inhibition reduced brain injury (132). CC chemokines also lead to expression and secretion of Regulated upon Activation, Normal T-cell Expressed, and Secreted, also known as C-C motif ligand 5 (CCL5) on T cells (123). CCL5 mediates the migration and adhesion of leukocytes through three different types of $\mathrm{G}$ protein-coupled receptors (CCR1, CCR3, and CCR5). Victoria et al. (133) confirmed that CCR5 deficiency led to improvement of neurological deficits and reduction of infarct volume against R/I. CCL5 also forms a heterodimer with CXCL4 and constitutes a CXC subgroup. CXCL4-CCL5 enhances the effect of CCL5, which contributes to ischemia-induced inflammation and brain injury, against which a CXCL4/CCL5 inhibitor protects (134).

\section{Cell Adhesion Molecules}

Cell adhesion molecules (CAMs) are involved in the trafficking and recruitment of leukocytes to activated ischemic endothelia in stroke. They contribute to the inflammatory response and worsen ischemic brain injury (135). CAMs are divided into three subgroups; the immunoglobulin superfamily [ICAM-1, 2, VCAM-1, platelet-endothelial cell adhesion molecule-1 (PECAM-1), the mucosal adhesion (MAdCAM-1), and activated leukocyte cell adhesion molecule], selectins [P-selectin (CD62P), E-selectin (CD62E), and L-selectin (CD62L)], and integrins (CD11, CD18, CD29, and CD49) (20). Following stroke, high levels of CAMs are expressed on cerebral endothelium, which lead to the recruitment and rolling of leukocytes and platelets in the cerebral microvasculature. When these rolling leukocytes approach activated endothelium, they adhere firmly to endothelial cells, after which transendothelial migration occurs leading to infiltration of ischemic brain $(20,61,66)$. These processes are also thought to be responsible for the "no flow phenomenon" of endothelial dysfunction.

Selectins as therapeutic targets have also been studied in the past. Goussev et al. (136) showed that administration of anti-Pselectin antibody reduced ischemic injury and HTf in a stroke model. Huang et al. (137) also reported the same for antibodies against anti-E-selectin. In contrast, the role of L-selectin, which presents on leukocytes and mediates leukocyte transmigration, is unclear. When it encounters activated endothelium, it is shed from the cell surface. However, it may not influence ischemic and I/R injury, as studies to inhibit it have not been shown to improve outcome or influence leukocyte infiltration in stroke models (61).
Integrins are distributed on the cell surface and contribute to cell-extracellular matrix (ECM) adhesion (138). They exist as heterodimers which consist of $\alpha$ and $\beta$ subunits. The migration of leukocytes is regulated by a specific integrin, which associates with a common $\beta_{2}$ chain (CD18). When leukocytes adhesion occurs, integrin CD18 binds to ICAM-1. Several $\alpha$ chains [e.g., CD11a (LFA-1) and CD11b (Mac-1)] combine with CD18 prior to adhesion to ICAM-1. Both Mac-1 deficiency and antibody inhibition of this integrin led to decreased stroke size and numbers of infiltrated neutrophils (61). In addition to leukocytes, monocytes and lymphocytes express other integrins composed of the $\beta_{1}$ (CD29) and $\beta_{7}$ (CD103) subunits. These subunits combine with the $\alpha_{4}$ integrin (CD49d) and interact with VCAM-1, MAdCAM-1, and the subendothelial matrix $(61,139)$.

Immunoglobulin superfamily members are also cell surface glycoproteins, which are expressed on endothelial cells, leukocytes, platelets, fibroblasts, and epithelial cell (20, 61). ICAM-1 (CD54) exists constitutively at low levels, and it is upregulated by cytokines following ischemia (20). Kitagawa et al. (140) and Zhang et al. (141) reported that ICAM-1 deficiency or anti-ICAM-1 therapy reduced ischemic injury and leukocyte adhesion. VCAM-1 (CD106) is upregulated by proinflammatory cytokines TNF- $\alpha$ and IL-1. Although PECAM-1 (CD31) is not upregulated by cytokines, it plays an important role in endothelial cell adhesion and leukocytes transmigration (142). Liesz et al. (143) also found that VCAM-1 deficiency reduced T lymphocyte infiltration into the brain and reduced infarct volume. Studies of CD49d inhibition in two different ischemic stroke models (tMCAO and pMCAO) showed that infarct volume was reduced and leukocyte infiltration was suppressed (144).

However, the efficacy of antiadhesion molecule strategies has not been established at the clinical level. The Enlimomab trial, which evaluated the efficacy of an ICAM-1 antibody in acute IS patients, showed that was antibody-treated patients actually had worsening of neurological function, increased mortality and fever compared to the placebo group. The HALT and Acute Stroke Therapy by Inhibition of Neutrophils (ASTIN) studies, which examined strategies to target the CD11/CD18 leukointegrin were both negative, and were stopped early due to lack of efficacy (145).

\section{Immune Molecule Effectors Matrix Metalloproteinase}

Matrix metalloproteinases are a family of zinc-binding endopeptidases responsible for the ECM turnover and digestion of proteins (146). A variety of subtypes are classified based on structural similarity; collagenases, gelatinases, metalloelastases, stromelysins, membrane-type MMPs, and others (147). These proteases normally participate in wound healing, bone remodeling, angiogenesis and other physiological processes (61). However, inflammatory stimuli can lead to the activation of MMPs from their inactive proform to their cleaved active form through signaling via several proinflammatory cytokines (IL-1 $\beta$ ) and chemokines (CCL-2, 7, 8, and 13) (148, 149). In stroke, MMPs have also been shown to participate in R/I. Activated MMP-2 and MMP-9 are known to contribute to the inflammatory response in acute ischemic stroke $(147,150)$. Microglia are a major source 
of MMPs (61) and activated MMPs have been detected within a few hours after ischemia onset and detected even 5 days later (61, 147). Activated MMP-2 and MMP-9 lead to the digestion of the endothelial basal lamina, including the degradation of tight junction proteins. This leads BBB disruption and secondary injury, causing brain edema and hemorrhagic transformation (151). tPA, which is present endogenously, also contributes to $\mathrm{BBB}$ and ECM disruption. Through its ability to activate plasmin, tPA indirectly activates MMPs, especially MMP-9, which is expressed by immune cells (151). In the setting of treatment with recombinant $\mathrm{PA}$ (rt-PA), this could result in more severe $\mathrm{BBB}$ disruption and hemorrhage, both feared complications of pharmacological thrombolysis. Hence, MMP inhibition may be a particularly important means of reducing I/R injury.

Matrix metalloproteinase-9-deficient mice had smaller infarcts following tMCAO (152), and chimeric studies showed that MMP-9 expressed particularly by leukocytes contributed to worsened stroke outcome (153). Clinical studies showed that serum MMP-9 levels correlated with stroke severity, with MMP-9 mRNA as a predictor of poor outcome (154).

Matrix metalloproteinase-2 has similar properties as MMP-9; however, its roles in ischemic stroke are still unclear. Previous reports showed that MMP-2 deficiency in experimental stroke and serum MMP-2 levels in stroke patients did not affect ischemic lesion size or stroke severity, respectively (155). Yet, MMP-2 activity increases in the later phase of ischemic stroke (147) and basal MMP-2 levels were higher in patients with stable or recovering symptoms (156). MMP-2 elevations, at least in the acute phase of ischemic stroke, might also be associated with better clinical outcomes.

\section{Inducible Nitric Oxide Synthase/Nitric oxide}

Nitric oxide is synthesized from L-arginine and oxygen through nitric oxide synthase (NOS) (157). Three NOS isoforms are known: endothelial NOS (eNOS), neuronal NOS (nNOS), and iNOS (158). iNOS is increased in immune cells including leukocytes, microglia, macrophage, and possibly astrocytes in response to proinflammatory stimuli, while eNOS and nNOS exist in the vascular endothelium and neurons, respectively (159). Damaging effects of NO derived from iNOS have been shown in experimental stroke. Iadecola et al. (160) and Zhao et al. (161) reported that inhibition or deficiency of iNOS reduced infarct size and improved neurological outcomes. High serum levels of iNOS have also correlated with a worse outcome (162).

\section{ROS/NADPH Oxidase}

While ROS are generated from a variety of sources following stroke, immune cells generate ROS as part of their microbicidal functions. Several pro-oxidant enzymes exist within immune cells, but substantial work pertaining to stroke has centered around NADPH oxidase (NOX) $(163,164)$. NOX is a multicomponent enzyme consisting of six subunits within the plasma membrane subunits (gp91 ${ }^{\text {phox }}, \mathrm{gp} 22^{\text {phox }}$ ) and cytoplasm (gp47 $7^{\text {phox }}$, gp67phox, gp $40^{\text {phox }}$ and Rho family GTPases) (163). After activation, NOX is phosphorylated, and the cytoplasmic subunits translocate to the membrane and form a complete complex on the cell surface. When this occurs, superoxide is generated from oxygen by electron transfer from NADPH $(163,165)$. Different isoforms of NOX have been identified, with NOX1, 2, and 4 being described in ischemic injury (166-168). In experimental stroke models, deficiency of both gp91 $91^{\text {phox }}$ and gp $47^{\text {phox }}$ NOX subunits reduced lesion size, immune cell activation, and superoxide generation, as did pharmacological inhibition with apocynin (169). NOX4 was also shown to be a relevant therapeutic target, as its inhibition or deletion led to protection (170). These investigators also showed that NOX4 was a major source of oxidative stress.

\section{Transcriptional Regulation of Inflammation}

Several transcription factors have been identified as regulators of the ischemic inflammatory response and also represent potential targets for intervention.

\section{Nuclear Factor $\kappa \mathrm{B}$ (NF-кB)}

Nuclear factor- $\kappa \mathrm{B}$ is a major transcription factor which contributes the inflammatory response, and has been documented in brain ischemia models (171). NF- $\mathrm{\kappa B}$ exists as heterodimer composed of p65 (RelA) and p50 in the cytosol and bound by its inhibitor protein $\mathrm{IkB}$. In the presence of an activating stimulus, IkB's kinase phosphorylates IkB, freeing NF- $\kappa B$ to translocate to the nucleus where it binds its consensus sequences to upregulate many proinflammatory genes. Since NF- $\mathrm{\kappa B}$ also upregulates genes involved in cell growth, its role is as a therapeutic target is still unclear and data are conflicting. On the one hand, deficiency or pharmacological inhibition of NF- $\mathrm{BB}$ was protective in some experimental stroke models $(172,173)$, but studies using a different inhibitor (diethyldithiocarbamate) found that this led to worsened outcome. Reasons for these discrepancies have been explained by the type of inhibitor used or whether NF- $\kappa$ B might be protective in some cell population, but damaging in others. Thus, treatment strategies specific targeting of NF- $\mathrm{\kappa B}$ to differentially inhibit proinflammatory while upregulating prosurvival genes may be necessary.

\section{Mitogen-Activated Protein Kinase (MAPK)}

Mitogen-activated protein kinase has also been studied in ischemia-induced inflammation (174). It is involved in the regulation of inflammatory gene expression and apoptosis (175). Its three interlinked MAPK signaling pathways have been assessed in experimental stroke models; p38 MAPKs, stress-activated protein kinases/c-Jun N-terminal kinases (SAPK/JNK), and extracellular signal-regulated kinases (ERKs) (61). In particular, p38 MAPK activation has been documented in the production and activation of several inflammatory molecules in microglia, astrocytes, and neurons $(175,176)$. p38 MARK activation occurs via several kinases: MLK3, MKK3/MKK6, and MKK4. NO regulates the activity of $38 \mathrm{MARK}$ through phosphorylation and S-nitrosylation. Inhibition of p38 MARK activation by SB239063 has been shown to protective against ischemic brain injury via suppression of proinflammatory cytokine/chemokine expression and synaptic dysfunction (177).

\section{Complement System}

Complement system also plays crucial roles in association with IS and R/I and consists of secreted and membrane-bound proteins 
(178). When this system is activated, three major pathways are involved in its activation: the classical pathway (CP), the alternative pathway (AP), and the lectin pathway (LP). Once ischemia occurs, the complement system is activated via both of CP and LP (179). This complement cascade contributes to microglial activation, leukocyte adhesion and recruitment, promotion of phagocytic system, and direct cellular lysis (178-181). Several studies have been performed using experimental stroke models. Especially in the LP, mannose-binding lectin (MBL), which binds with the natural self-reactive $\operatorname{IgM}$ antibody and a LP-specific protease called mannan-binding lectin-associated serine proteases (MASPs)-2 have been recognized as key players. Antibody-deficient $\left(\operatorname{Rag} 1^{-/-}\right)$or MBL-deficient mice exposed to experimental stroke were found to have reduced brain injury $(182,183)$. MASPs-2 antibody treatment also reduced infarct volume and improved neurological deficits in a similar model (179). In association with C3 cleavage, inhibition of complement receptor 2 which binds to $\mathrm{C} 3 \mathrm{~d}$, led to the reduction of $\operatorname{IgM}$ and complement deposition, P-selectin, and neutrophil infiltration in experimental stroke (178).

\section{Damage-Associated Molecular Patterns}

Recent work has begun to identify factors which trigger the inflammatory response in stroke and related insults. Like pathogen-associated molecular patterns (PAMPS), DAMPS include several molecules elaborated by injured cells which are able to bind any number of immune receptors. Some which have been identified in stroke and related brain injury models include high mobility group box-1, heat shock proteins, peroxiredoxin, nucleic acids, purines, and $\beta$-amyloid $(61,184)$. Neurons appear to be an early source of DAMPs in stroke. The complement system and several immune receptors recognize DAMPs and induce inflammation following IS and in association with R/I. Targets of DAMPs include several innate immune receptors, and those most studied in cerebral ischemic include the TLRs and purinergic receptors.
Toll-like receptors are present on the cell surface and act as a sensor of the innate immune response. TLR2 and TLR4 have been the most studied of these in stroke models (185). Following ischemic insults, brain cells elaborate DAMPs which then stimulate TLR2 and TLR4 $(22,184)$. Through TLR signaling, inflammatory responses including microglial activation, induction of proinflammatory cytokines, neutrophil/lymphocyte infiltration, and NF- $\mathrm{BB}$ activation lead to brain injury. A few studies have shown that deletion or inhibition of these TLRs improve experimental stroke outcome, whereas their overexpression exacerbates it $(186,187)$. However, one report showed that mice lacking TLR2 had larger infarcts and increased mortality (188) and another showed that TLR2 and TLR4 deficiency in microglia failed to ameliorate ischemic injury (189).

As mentioned previously (see Microglial/Macrophage Activation), purinergic receptors have also been studied in stroke models. Purinergic receptors bind purines, including ATP and UDP, and when activated, lead to immune cell chemotaxis and phagocytosis $(190,191)$. Deficiency of the P2Y12 purinergic receptor led to improved neurological outcome and reduced microglial migration (55). Of particular relevance to stroke, the P2Y12 purinergic receptor can be inhibited by the commonly used antiplatelet drug clopidogrel.

\section{ANTI-INFLAMMATORY TREATMENTS}

Several treatments to prevent ischemia-induced inflammation and modulate immune response have been studied in both experimental stroke and clinical trials (Table 1), which we review here.

\section{Minocycline}

Minocycline is a semisynthetic tetracycline antibiotic which has pleiotropic actions (243). This agent has been shown to improve chronic inflammation in several models of neurological diseases including experimental stroke (192). Rodents subjected to focal and global cerebral ischemia showed neurological improvement

TABLE 1 | Neuroprotective agents and therapies for ischemia-induced inflammation and reperfusion injury in experimental stroke models and clinical trials.

\begin{tabular}{|c|c|c|c|c|}
\hline Neuroprotective agent/therapy & Animal model & Infarct volume & $\begin{array}{l}\text { Neurological } \\
\text { outcome }\end{array}$ & Clinical trial \\
\hline Minocycline (192-204) & $\begin{array}{l}\text { temporary middle cerebral } \\
\text { artery occlusion (tMCAO) rat }\end{array}$ & Reduced & Improved & Better outcome (small trial) \\
\hline Integrin $(205,206)$ & tMCAO rabbit & Reduced & - & No efficacy \\
\hline Anti-ICAM-1 antibody $(207,208)$ & tMCAO mice & Reduced & - & No efficacy \\
\hline Anti-IL-1receptor agonist $(95,209)$ & tMCAO rat & Reduced & - & Better outcome (small trial) \\
\hline Edaravone (210-216) & tMCAO rat & Reduced & Improved & Better outcome \\
\hline Simvastatin (217) & tMCAO rat & Reduced & Improved & $\begin{array}{l}\text { No efficacy (combined with tissue } \\
\text { plasminogen activator) }\end{array}$ \\
\hline Rosuvastatin (218) & tMCAO rat & Reduced & Improved & - \\
\hline Pioglitazone (219) & tMCAO rat & Reduced & - & - \\
\hline Sitagliptin (220) & tMCAO rat & $\begin{array}{l}\text { Reduction of inflammatory } \\
\text { mediators }\end{array}$ & & - \\
\hline Fingolimod (221-229) & tMCAO rat & Reduced & Improved & Better outcome \\
\hline Natalizumab (230-232) & tMCAO rat & Reduced & Improved & Better outcome (small trial) \\
\hline Cyclosporine A $(233,234)$ & tMCAO rat & Reduced & Improved & No efficacy \\
\hline Glatiramer (235) & tMCAO mice & No efficacy & No efficacy & - \\
\hline Intravenous immunoglobulin therapy (236) & tMCAO mice & Reduced & Improved & - \\
\hline Hypothermia (237-242) & tMCAO rat & Reduced & Improved & Better outcome \\
\hline
\end{tabular}


with correlations to anti-inflammatory, antioxidant, and antiapoptotic effects with a somewhat wide temporal therapeutic window of at least $4 \mathrm{~h}$ (193-197). In fact, in one study showed that delaying minocycline treatment even 4 days post-tMCAO and continued for 4 weeks led to improved motor and cognitive functions and reduced microglial activation and improved neurogenesis (198). A major mechanism of neuroprotection is thought to be due to its ability to suppress microglial activation via inhibition of the MAPK p38 pathway and NLRP3 inflammasome signaling (194). Minocycline treatment was correlated with the reduction of several proinflammatory cytokines, as well as ROS and NO (197, 199). Minocycline also improved BBB viability and integrity by promoting neurovascular remodeling via MMP inhibition $(195,197)$. Monocyte chemotactic proteininduced protein1 (MCPIP1), which is expressed in monocytes following exposure to MCP-1, has also been shown to be an important mediator of minocycline-induced neuroprotection. Minocycline upregulated MCPIP1 in neurons and microglia and MCPIP1 inhibits expression of proinflammatory cytokines due to negative regulation of NF- $\kappa \mathrm{B}$ signaling pathways (199).

Minocycline has also been studied in combination therapy. For example, minocycline and aspirin led to reduction of ischemic injury, brain edema, BBB disruption, and neurological dysfunction in diabetic rats subjected to tMCAO (200). MMP-2 and MMP-9 were both suppressed by treatment, as were cyclooxygenase- 2 and tPA. In combination with cell based therapy, minocycline induced the pleiotropic protein Nrf2, which provided an antioxidant effect that protected transplanted neural stem cells in a stroke models (201, 202). Normobaric hyperxia plus minocycline also demonstrated synergistic effects, with greater protection together than each intervention alone.

Finally, minocycline has also been studied in a few clinical trials. In a small study, oral minocycline contributed to better outcomes as measured by lower National Institute of Health Stroke Scale [NIHSS] and modified Rankin Scale [mRS] scores, and higher Barthel Index [BI] in patients with acute ischemic stroke (203). Intravenous minocycline therapy was associated with reduced MMP-9 levels in stroke patients (204). Since minocycline is already in clinical use for other indications and has an acceptable safety profile, it could be considered as an adjunctive treatment to pharmacological thrombolysis and/or mechanical thrombectomy. Because it already in clinical use for other indications, minocycline could conceivably be given to acute IS patients.

\section{Fingolimod (FTY720)}

FTY720 is a lipophilic immunomodulatory sphingosine-1-phosphate (S1P) analog, which is now used for treatment of multiple sclerosis and prevents T-lymphocyte egress from lymphoid organs (244). FTY720 reduces R/I to the other organs such as kidney, liver, and heart in the laboratory $(221,222)$. Studies in cerebral ischemia have similarly shown reduction in I/R injury and improvement in neurological function (223). One study even modeled a clinically relevant scenario of experimental thromboembolic stroke and combination treatment with fingolimod and rt-PA. This study found not only improvement in neurological outcome but also reduction in HTf (224).
FTY720 is known to act differential S1P receptors (-1 [S1P1], -3 [S1P3], -4 [S1P4], and -5 receptors [S1P5]) (225). Phosphorylated FTY720 mainly binds to lymphocyte S1P1 receptors in neuron and contributes to anti-inflammatory effect due to reduction of T-lymphocyte infiltration and proinflammatory cytokines (IFN- $\gamma$, IL-17) (226). S1P1 also plays an important role in enhancing BBB integrity (225). Once ischemic stroke occurs, S1P levels are increased and S1P-related enzymes are upregulated in the injured brain. In experimental stroke, FTY720 is associated with activation of prosurvival factors Akt and ERK (226). In addition to S1P1, FTY720 was also thought to signal through the S1P3 receptor (227). In addition to S1P receptor-related mechanisms, FTY720 may directly act to suppress microglia/macrophage activation and reduce proinflammatory cytokines, neutrophil infiltration and downregulate adhesion molecules (e.g., ICAM-1) $(221,225)$. FTY720 appears to have at least two temporal therapeutic windows ranging from 1 to 3 or 4 days after ischemia (suppression of microglial activation) and up to 14 days after ischemia (suppression of T-lymphocytes infiltration).

However, some studies failed to show any benefit of fingolimod. FTY720 treatment in pMCAO did not affect stroke outcome, findings that might suggest that any beneficial effect is through mechanisms exclusive to R/I $(228,229)$. Yet another study failed to show any benefit when fingolimod was given in combination with rt-PA, thus contradicting the results of the above referenced investigation (245).

There is some experience with fingolimod at the clinical level. In addition to its use in multiple sclerosis where it has been shown to improve disease course, FTY720 has been studied in ischemic stroke patients. Fu et al. (246) administered FTY720 6-72 h poststroke to patients with anterior cerebral circulation syndromes for 3 days. They reported that oral FTY720 could be given safely and improved neurological recovery at 90 days. FTY720 treatment also decreased microvascular permeability and circulating lymphocyte counts. While clinical experience is still limited at this point, it may be worthwhile to pursue larger trials.

\section{Neutrophil and Cytokine Inhibition}

Antineutrophil interventions to prevent neutrophil infiltration, trafficking and/or activation have been studied at both the laboratory and clinical levels. Several reports of neutrophil depletion led to reduced infarct volume and infiltrated brain neutrophil counts $(66,71-73)$. Pharmacologically blocking leukocyte adhesion and migration into ischemic brain were performed in several experimental models with salutary results $(102,205)$ that led to the design of a few clinical studies using antibodies against adhesion molecules such as ICAM-1 and CD11/CD18 or by administering neutrophil inhibiting factor in the $\operatorname{ASTIN}$ trial $(76,206)$. However, none these studies were efficacious. In fact, the study of an anti-ICAM-1 antibody not only showed lack of benefit but also showed that this treatment made patients worse $(207,208)$.

Cytokine inhibiting strategies have also been studied at the clinical level. In one phase II trial, human recombinant IL-1 receptor antagonist (IL-1Ra), IL-1's endogenous inhibitor, was studied (209). In this trial, inflammatory molecules were decreased among IL-1Ra-treated patients and these patients also had improved neurological function and smaller infarct volumes. 


\section{Hypothermia}

Hypothermia (HT) has been lauded as the prototypical neuroprotectant, and clinical studies have shown that mild to moderate cooling improves neurological outcomes following cardiac arrest and neonatal hypoxia ischemia (237). While it has yet to be shown as improving in clinical stroke outcome, several laboratory studies have shown it to be robustly protective. Particularly in tMCAO, HT appears to be robust across several laboratories and experimental models $(238,239)$. One mechanism underlying its beneficial effect is that therapeutic cooling seems to have remarkable effects on suppressing inflammation (240). Reduction of inflammatory molecules by HT therapy has been shown by several groups, including proinflammatory cytokines (IL-1 $\beta$, TNF- $\alpha$, IL-6), MMPs (MMP-9, MMP-2), and NF-кB (241). HT has been suggested as an adjunctive treatment in ischemic stroke including I/R injury $(242,247)$. Relevant to cotreatment with rt-PA, HT has been shown in the laboratory to extend the therapeutic time-window of other neuroprotectants, sometimes extending the therapeutic window from 2 h to over 2 months, in some cases (242). Combination therapy with HT and rt-PA at the experimental level has revealed varying results (248), but such a combination did not appear to increase HTf or increase mortality (249).

At the clinical level, the ICTuS2 study examined HT in acute stroke and included patients who were eligible for treatment with rt-PA (250). This study showed that both HT and HT plus rt-PA were both safe and feasible, but cooling increased the risk of pneumonia. In a different study, Hong et al. (247) reported in a small study that mild HT therapy (temperatures of $34.5^{\circ} \mathrm{C}$ ) for $48 \mathrm{~h}$ followed by $48 \mathrm{~h}$ of rewarming led to reduction of HTf and brain edema and better clinical outcomes.

\section{Others}

Edaravone is an antioxidant and ROS scavenger marketed as a neurovascular protective agent (210). Okamura et al. (211) reported that edaravone reduced infarct volume, brain edema, and HTf $24 \mathrm{~h}$ after stroke in tMCAO in rats. This was also correlated with reduction in inflammatory molecules, proinflammatory cytokines (IL-1 $\beta$ and IL-6), chemokines (fractalkine), and MMP-9 (210). At the clinical level, neurological function including NIHSS and BI was improved and several adverse events (HTf, pulmonary infection, stroke recurrence, and seizures) were also reduced by edaravone $(212,213)$. Edaravone is already approved for the treatment of ischemic stroke patients who present within $24 \mathrm{~h}$ of the onset of symptoms in Japan and other countries, but not the United States (251).

3-Hydroxy-3-methylglutaryl-coenzyme A reductase inhibitors (statins) are used for treatment of dyslipidemia and are nearly routinely prescribed for secondary prevention of stroke (252). Statins have been also studied as neuroprotectants in experimental stroke (253). Statins have been correlated with upregulation of eNOS, inhibition of ROS-induced lipid peroxidation, reduction of superoxide as well as anti-inflammatory effects (254). A variety of statins have been shown to reduce infarct volume and improve neurological deficit in experimental stroke (217). Rosuvastatin was also shown to reduce R/I by inhibiting oxidative stress and inflammatory responses such as reducing superoxide and NOX, inhibiting microglial activation, and downregulating of inflammatory molecules (NF- $\kappa \mathrm{B}$, iNOS) (218). In clinical studies, Simvastatin has been shown to reduce subsequent strokes and improve neurological function, but efficacy has not been shown in combination with tPA $(255,256)$.

Several antidiabetic drugs have been shown to have a neuroprotective effect. Kumari et al. (257) reported that treatment with peroxisome proliferator-activated receptor $\gamma(\operatorname{PPAR} \gamma)$ agonist attenuated infarct volume and reduced inflammatory responses in experimental stroke. Generally, PPAR $\gamma$ activation in monocytederived macrophage has been thought to influence macrophage polarization (258). It also affects ischemia-induced inflammation and HTf (257). Hence, PPAR $\gamma$ agonists act not only to decrease serum glucose levels but also to decrease inflammation. Further, the PPAR $\gamma$ agonist pioglitazone not only protected from tMCAO but also was associated with antioxidant and antiapoptotic effects in addition to anti-inflammatory effects in diabetic rats subjected to tMCAO (219). PPAR $\gamma$ agonists have pleiotropic effects against ischemia/R/I, as do dipeptidyl peptidase-4 inhibitors. In a recent study of diabetic rats subjected to experimental stroke, sitagliptin administration give before $\mathrm{I} / \mathrm{R}$ was shown to suppress NF- $\kappa \mathrm{B}$ signaling (220). In parallel, it was also shown to be anti-inflammatory, antioxidant, and antiapoptotic.

Other immunosuppressive agents used for inflammatory diseases have been also evaluated for anti-inflammatory and neuroprotective effects in ischemic stroke. Natalizumab, a humanized monoclonal antibody to CD49d, has been used for treatment of multiple sclerosis. Similar approaches have also been studied in acute ischemic stroke (230). Using a related antibody, Relton et al. (231) treated rats subjected to tMCAO with antibody to the CD49d into and showed that it reduced infarct volume and improved neurological deficits. Treatment also led to reduction of lymphocyte infiltration and VCAM-1 upregulation. However, other studies did not show efficacy using this approach. The ACTION clinical trial explored safety and efficacy of natalizumab in stroke (232). Natalizumab did not affect infarct volume or neurological outcomes (mRS and BI) at 90 days; thus, it seems unlikely that natalizumab might be further developed for this indication. There are also side effects occasionally seen in patients with multiple sclerosis treated with this agent. Glatiramer is another compound used in the treatment of MS (259). Its anti-inflammatory mechanism is still unclear, but it appears to inhibit Th1 proinflammatory cytokines, while inducing $\mathrm{Th} 2 / \mathrm{T}_{\text {reg }}$ activation. Kraft et al. (235) studied glatiramer in an experimental stroke model. While microglial activation and proinflammatory cytokine generation were suppressed, it failed to reduce ischemic lesion volume and neurological deficits. Cyclosporine A, a calcineurin inhibitor used for variety of immune diseases, in stroke models led to the reduction of infarct size and inflammation through the suppression of cytokines, $\mathrm{T}$ cell activation, and ROS production, but failed to show efficacy in clinical trials $(233,234)$. Finally, intravenous immunoglobulin (IVIG) therapy has been shown to have neuroprotective and anti-inflammatory effects in ischemic stroke models by modulating the TLRs and MARK pathways (236). While IVIG is used routinely at the clinical level for other indications, it has yet to be studied in stroke patients. 


\section{ANTI-INFLAMMATORY TREATMENT COMBINED WITH ACUTE REVASCULARIZATION}

Recent studies have demonstrated the efficacy of anti-inflammatory treatments in combination with rt-PA in experimental stroke models. A few clinical studies have similarly focused on combined endovascular treatment (EVT) with anti-inflammatory agents (Table 2).

\section{Pharmacological Thrombolysis}

The benefit of rt-PA therapy has been established in clinical trials $(1,2)$ but its therapeutic time-window is limited to $3-4.5 \mathrm{~h}$ from symptoms onset (267). Thus, patients who can receive rt-PA therapy are still limited (3.4-5.2\% of all patients with acute ischemic stroke) and this is largely due to the risk of R/I, particularly the complication of cerebral hemorrhage which can worsen outcome and increase mortality (268). tPA is a serine protease and can thus promote ECM damage which can lead to HTf (269). Hence, combined therapy with agents that suppress inflammatory molecules, thus preventing $\mathrm{BBB}$ disruption and downstream effects such as edema and hemorrhage seem viable approaches.

As described in section "Others," edaravone is generally used for acute IS treatment. Combination treatment with edaravone and rt-PA is also already used at the clinical level in Japan. The PROTECT4.5 trial compared rt-PA with rt-PA plus edaravone in acute ischemic stroke patients within $4.5 \mathrm{~h}$ after symptom onset. This study showed that combination therapy accelerated recanalization and reduced the incidence of cerebral hemorrhage (214). The YAMATO study was then carried out to determine whether early (vs. late) edaravone infusion promoted early recanalization and reduced complications, but failed to show any difference in outcome with either paradigm (215).

Combination treatment with rt-PA and hypothermia has been also studied both in the lab and at the clinical level, as described in section "Hypothermia." Tang et al. (249) reported that rt-PA plus HT reduced brain hemorrhage, $\mathrm{BBB}$ disruption in mice exposed to $\mathrm{TMCAO}$. They also showed that HT reduced endogeneous $\mathrm{PAA}$ expression. In a clinical trial [Reperfusion and Cooling in Cerebral Acute Ischemia (ReCCLAIM)], Horn et al. (270) showed that HT could be carried out safely after tPA therapy in patients with large infarcts. This study also suggested that this approach could reduce $\mathrm{R} / \mathrm{I}$, as outcomes were improved compared to stroke patients who did not received HT.

While minocycline did not affect rt-PA's fibrinolytic activity and clot lysis when given in combination in an experimental stroke model (260). Fan et al. (261) reported that the combination therapy of rt-PA with minocycline was effective in hyperglycemia/type 1 diabetes rats subjected to focal cerebral ischemia. In this study, they showed that neutrophil infiltration, microglia activation, MMP-9 activity and tight junction protein claudin-5 degradation was reduced with combination therapy, compared to rt-PA alone. Minocycline is expected to reduce acute inflammatory cascades stimulated by thrombolysis. Kohler et al. (262) demonstrated the safety of this combination therapy in a pilot clinical study; however, efficacy in this small study could not be demonstrated, thus, emphasizing the need for future a larger clinical trial.

Progranulin (PGRN), a growth factor induced in the brain via estrogen, may prove to be a novel adjunctive treatment to rt-PA (271.) PGRN has been also reported to inhibit inflammatory reactions in stroke models. In tMCAO, PGRN increases especially within microglia and vascular endothelial cells $24-72 \mathrm{~h}$ after reperfusion (263). PGRN is thought to contribute anti-inflammatory and vaso-protective properties. PGRN knockout mice subjected to stroke had decreasing IL-10 levels with increasing VEGF levels compared to wildtype (263). Combination therapy with rt-PA and PGRN was beneficial in a stroke model where it not only reduced infarct size, it also reduced complications of R/I such as brain edema and hemorrhage, while improving neurological functions.

Granulocyte-colony stimulating factor (G-CSF) is thought to provide neuroprotection due to its anti-inflammatory effect (272). dela Peña et al. (264) reported that combined therapy with rt-PA and G-CSF reduced HTf and improved of neurological function $24 \mathrm{~h}$ after tMCAO rats, compared with rats receiving only rt-PA. G-CSF may also be expected to enhance endothelial cell survival and reduce their activation; thus, this combination may prevent BBB disruption and reduce HTf. Although G-CSF therapy in ischemic stroke patients has not been shown to be efficacious, its safety was proven for use in other diseases $(273,274)$. Future studies should focus on combination therapy of G-CSF and rt-PA.

Fingolimod has also been studied in combination with rt-PA. A pilot study showed that this combination was safe and had a possibility to reduced infarct volume, hemorrhage, and

TABLE 2 | Combined therapy with acute recanalization against ischemia-induced inflammation and reperfusion injury in experimental stroke models and clinical trials.

\begin{tabular}{|c|c|c|c|c|c|}
\hline Neuroprotective agent/therapy & Animal model & $\begin{array}{l}\text { Infarct } \\
\text { volume }\end{array}$ & $\begin{array}{l}\text { Neurological } \\
\text { outcome }\end{array}$ & $\begin{array}{l}\text { Hemorrhagic } \\
\text { transformation }\end{array}$ & Clinical trial \\
\hline Edaravon (214-216) & - & - & - & - & $\begin{array}{l}\text { Better outcome (with thrombolysis } \\
\text { and thrombectomy) }\end{array}$ \\
\hline Minocycline (260-262) & $\begin{array}{l}\text { temporary middle cerebral artery } \\
\text { occlusion (tMCAO) rat }\end{array}$ & Reduced & Improved & Reduced & Only safety (with thrombolysis) \\
\hline Progranulin (263) & tMCAO rat & Reduced & Improved & Reduced & - \\
\hline $\begin{array}{l}\text { Granulocyte-colony stimulating } \\
\text { factor (264) }\end{array}$ & tMCAO rat & Reduced & Improved & Reduced & - \\
\hline Fingolimod (265) & tMCAO mice & - & Not improved & - & $\begin{array}{l}\text { Better outcome (with thrombolysis, } \\
\text { small trial) }\end{array}$ \\
\hline Hypothermia $(247-250,266)$ & - & - & - & - & $\begin{array}{l}\text { Only safety (with thrombolysis and } \\
\text { thrombectomy) }\end{array}$ \\
\hline
\end{tabular}


TABLE 3 | Recent on going clinical trials of combined therapy with acute recanalization against ischemia-induced inflammation and reperfusion injury.

\begin{tabular}{|c|c|c|c|c|}
\hline $\begin{array}{l}\text { Trials } \\
\text { (neuroprotective } \\
\text { agent/therapy) }\end{array}$ & Study design & Patients number & Treatments & End point \\
\hline $\begin{array}{l}\text { RHAPSODY } \\
\text { (3K3A-APC) }\end{array}$ & $\begin{array}{l}\text { Randomized, } \\
\text { double-blined } \\
\text { study }\end{array}$ & $\begin{array}{l}n=110(\text { age } 18-90 \text { years } \\
\text { and NIHSS } \geq 5)\end{array}$ & $\begin{array}{l}5 \text { doses (120, 240, } 360,540 \mu g \text {, and placebo) } \\
\text { with rt-PA and/or EVT }\end{array}$ & $\begin{array}{l}\text { Safety, pharmacokinetics, and preliminary } \\
\text { efficacy of multiple ascending doses }\end{array}$ \\
\hline STARS07 (Simvastatin) & $\begin{array}{l}\text { Double-blind, } \\
\text { randomized, } \\
\text { controlled study }\end{array}$ & $n=340$ (age over 18 years) & $\begin{array}{l}\text { Combination of simvastatin (started within } 12 \mathrm{~h} \\
\text { from onset) plus rt-PA }\end{array}$ & Safety and efficacy \\
\hline SEATIS (Atorvastatin) & $\begin{array}{l}\text { Randomized, } \\
\text { open label study }\end{array}$ & $\begin{array}{l}n=256 \text { (age over } 18 \text { years } \\
\text { and mRS before onset less } \\
\text { than } 2 \text { ) }\end{array}$ & $\begin{array}{l}2 \text { different atorvastatin doses ( } 80 \text { and } 20 \text { mg) } \\
\text { within } 24 \text { h after intravenous rt-PA for at least } \\
2 \text { weeks }\end{array}$ & $\begin{array}{l}\text { Safety and efficacy (NIHSS, mRS, } \\
\text { mortality, hemorrhagic complications, } \\
\text { and recurrence) }\end{array}$ \\
\hline $\begin{array}{l}\text { ReCCLAIM-II } \\
\text { (hypothermia) }\end{array}$ & $\begin{array}{l}\text { Randomized, } \\
\text { open label study }\end{array}$ & $\begin{array}{l}n=85 \text { (age } \geq 18, \\
\leq 79 \text { years, ASPECTS } 5-10, \\
\text { NIHSS } 14-29, \text { mRS of } 2 \\
\text { before onset) }\end{array}$ & $\begin{array}{l}\text { Reducing body temperture (mild hypothermia of } \\
\left.33^{\circ}\right) \text { with acute revascularization (rt-PA and EVT), } \\
\text { compared to normothermia group }\end{array}$ & $\begin{array}{l}\text { Efficacy (hemorrhage conversion, } \\
\text { hyperintense acute reperfusion marker, } \\
\text { NIHSS, and mRS), safety (adverse } \\
\text { events) }\end{array}$ \\
\hline
\end{tabular}

rt-PA, recombinant tissue plasminogen activator; EVT, endovascular treatment; NIHSS, National Institute of Health Stroke Scale; mRS, modified Rankin Scale; ASPECTS, Alberta Stroke Programme Early CT Score.

neurological deficit in acute stroke patients (265). In addition to fingolimod's anti-inflammatory effects, it combination with rt-PA may also prevent BBB disruption, thus reducing hemorrhage risk.

\section{Endovascular Treatment}

Recent randomized controlled trials have shown the efficacy of EVT within 4.5-12 h after the onset of ischemic stroke (3). The stent retriever appears to be particularly effective and safer than earlier devices. However, the rate of good clinical outcomes by EVT is still limited and adjunctive neuroprotective/anti-inflammatory therapy may be desirable in order to reduce complications, likely results of R/I. Edaravone is already used in combination with EVT in Japan. The RESCUE Japan Registry analyzed the efficacy of edaravone in patients with acute cerebral large vessel occlusion (216). Edaravone was found to be more effective for the patients treated with IV rt-PA than EVT, although the reasons for difference were unclear.

Hypothermia has been used together with EVT. Chen et al. (266) reported that selective brain cooling by intra-arterial infusion of cold saline during endovascular recanalization was feasible and safe; however, this study did not assess efficacy.

\section{Ongoing Trials}

There are now several clinical trials evaluating the safety and efficacy of the combined therapy against ischemia-induced inflammation and R/I (Table 3). Activated protein C (APC) is an endogenous serine protease which has been detected in both neurons and endothelial cells (275). APC can suppress microglial activation and leukocyte infiltration via the suppression of NF- $\mathrm{KB}$ and proinflammatory cytokines and adhesion molecules. APC also activates a family of G-protein coupled protease-activated receptor1 and prevents BBB disruption (276). Thus, APC may be a novel adjunctive therapy to EVT because of its anti-inflammatory and BBB stabilizing properties. The "Safety Evaluation of 3K3A-APC in Ischemic Stroke (RHAPSODY)" trial (NCT02222714) which studies the safety and efficacy of adjunctive APC with rt-PA, mechanical thrombectomy, or both is ongoing (276).
In preclinical studies, statins have been shown to have neuroprotective properties through their ability to upregulate eNOS (277). Now, there are a few clinical trials to evaluate their efficacy in combination with reperfusion strategies. "Stroke Treatment with Acute Reperfusion and Simvastatin (STARS07)" trial and "The Safety and Efficacy Study of High Dose Atorvastatin after Thrombolytic Treatment in Acute Ischemic Stroke (SEATIS)" trial (NCT02452502) are undergoing to evaluate the efficacy (mortality, recurrence, ischemic lesion volume, HTf, NIHSS, BI, and $\mathrm{mRS}$ ) and safety.

There is also another clinical trial in progress to study neuroprotective therapy in association with acute recanalization against ischemia-induced inflammation and R/I. The "ReCCLAIM-II" trial (NCT02411877) compares mild hypothermia to normothermia in patients treated with rt-PA and/or EVT and evaluates its effect on neurological efficacy, hemorrhagic conversion, and imaging markers of $\mathrm{R} / \mathrm{I}$.

\section{CONCLUSION}

Inflammation and $\mathrm{R} / \mathrm{I}$ following ischemic stroke can worsen outcome, and this issue becomes particularly important now that there are two broad categories of effective acute revascularization treatments. In this review, we focused mainly on inflammatory mechanisms and targets to prevent R/I. In reviewing the literature, many experimental studies did not necessarily focus on reperfusion as a target, but inflammation modulating interventions for neuroprotection. Similarly, the many failed clinical stroke studies of neuroprotection were carried out before these treatments were approved. There are certainly differences between clinical trials and experimental models regarding the mechanisms of reperfusion (or lack of reperfusion in early clinical studies) and the alignment or misalignment of treatment timing. However, recent progress in acute revascularization at the clinical level open the possibility of revisiting neuroprotectants to further improve outcomes in a synergistic manner. As we are now in the age of restoring CBF, it seems worthwhile to address these neuroprotective treatments 
once again. Perhaps combination therapies with anti-inflammatory treatments given to coincide with the onset of reperfusion should be the focus of future laboratory and clinical studies with purpose of determining whether adjunctive treatment may reduce complications, further improve neurological outcomes and even determine whether the time windows for intervention could be lengthened.

\section{AUTHOR CONTRIBUTIONS}

This review article was written by AM, including a thorough review of the literature and preparation of figures and table.

\section{REFERENCES}

1. Ahmed N, Wahlgren N, Grond M, Hennerici M, Lees KR, Mikulik R, et al. Implementation and outcome of thrombolysis with alteplase 3-4.5 h after an acute stroke: an updated analysis from SITS-ISTR. Lancet Neurol (2010) 9(9):866-74. doi:10.1016/S1474-4422(10)70165-4

2. Wardlaw JM, Murray V, Berge E, del Zoppo GJ. Thrombolysis for acute ischaemic stroke. Cochrane Database Syst Rev (2014) 7:CD000213. doi:10.1002/ 14651858.CD000213.pub3

3. Goyal M, Menon BK, van Zwam WH, Dippel DW, Mitchell PJ, Demchuk AM, et al. Endovascular thrombectomy after large-vessel ischaemic stroke: a meta-analysis of individual patient data from five randomised trials. Lancet (2016) 387(10029):1723-31. doi:10.1016/S0140-6736(16)00163-X

4. Thomalla G, Gerloff C. Treatment concepts for wake-up stroke and stroke with unknown time of symptom onset. Stroke (2015) 46(9):2707-13. doi:10.1161/STROKEAHA.115.009701

5. Jovin TG, Saver JL, Ribo M, Pereira V, Furlan A, Bonafe A, et al. Diffusionweighted imaging or computerized tomography perfusion assessment with clinical mismatch in the triage of wake up and late presenting strokes undergoing neurointervention with Trevo (DAWN) trial methods. Int J Stroke (2017) 12(6):641-52. doi:10.1177/1747493017710341

6. Lees KR, Bluhmki E, von Kummer R, Brott TG, Toni D, Grotta JC, et al. Time to treatment with intravenous alteplase and outcome in stroke: an updated pooled analysis of ECASS, ATLANTIS, NINDS, and EPITHET trials. Lancet (2010) 375(9727):1695-703. doi:10.1016/S0140-6736(10)60491-6

7. The National Institute of Neurological Disorders and Stroke rt-PA Stroke Study Group. Intracerebral hemorrhage after intravenous t-PA therapy for ischemic stroke. Stroke (1997) 28(11):2109-18. doi:10.1161/01.STR.28.11.2109

8. Bai J, Lyden PD. Revisiting cerebral postischemic reperfusion injury: new insights in understanding reperfusion failure, hemorrhage, and edema. Int J Stroke (2015) 10(2):143-52. doi:10.1111/ijs.12434

9. Schaller B, Graf R. Cerebral ischemia and reperfusion: the pathophysiologic concept as a basis for clinical therapy. J Cereb Blood Flow Metab (2004) 24(4):351-71. doi:10.1097/00004647-200404000-00001

10. Kuroda S, Siesjö BK. Reperfusion damage following focal ischemia: pathophysiology and therapeutic windows. Clin Neurosci (1997) 4(4):199-212.

11. Chan PH. Role of oxidants in ischemic brain damage. Stroke (1996) 27(6):1124-9. doi:10.1161/01.STR.27.6.1124

12. Yang GY, Betz AL. Reperfusion-induced injury to the blood-brain barrier after middle cerebral artery occlusion in rats. Stroke (1994) 25(8):1658-64. doi:10.1161/01.STR.25.8.1658

13. Zhao H, Yenari MA, Cheng D, Sapolsky RM, Steinberg GK. Bcl-2 overexpression protects against neuron loss within the ischemic margin following experimental stroke and inhibits cytochrome $\mathrm{c}$ translocation and caspase-3 activity. J Neurochem (2003) 85(4):1026-36. doi:10.1046/j.1471-4159.2003.01756.x

14. Aronowski J, Strong R, Grotta JC. Reperfusion injury: demonstration of brain damage produced by reperfusion after transient focal ischemia in rats. J Cereb Blood Flow Metab (1997) 17(10):1048-56. doi:10.1097/00004647199710000-00006

15. Karapanayiotides T, Meuli R, Devuyst G, Piechowski-Jozwiak B, Dewarrat A, Ruchat P, et al. Postcarotid endarterectomy hyperperfusion or reperfusion syndrome. Stroke (2005) 36(1):21-6. doi:10.1161/01.STR.0000149946.86087.e5
MY developed the outline, made revisions, and approved the final version.

\section{ACKNOWLEDGMENTS}

This work was supported by grants from the Veteran's Merit Award (I01 BX000589 to MY) and SENSIN Medical Research Foundation (2016 Research Fellowship to AM). Grants to MY were administered by the Northern California Institute for Research and Education and supported by resource of the Veterans Affairs Medical Center, San Francisco, CA, USA.

16. Wang YF, Tsirka SE, Strickland S, Stieg PE, Soriano SG, Lipton SA. Tissue plasminogen activator (tPA) increases neuronal damage after focal cerebral ischemia in wild-type and tPA-deficient mice. Nat Med (1998) 4(2):228-31. doi:10.1038/nm0298-228

17. Hossmann KA. The two pathophysiologies of focal brain ischemia: implications for translational stroke research. J Cereb Blood Flow Metab (2012) 32(7):1310-6. doi:10.1038/jcbfm.2011.186

18. Danton GH, Dietrich WD. Inflammatory mechanisms after ischemia and stroke. J Neuropathol Exp Neurol (2003) 62(2):127-36. doi:10.1093/ jnen/62.2.127

19. Iadecola C, Anrather J. The immunology of stroke: from mechanisms to translation. Nat Med (2011) 17(7):796-808. doi:10.1038/nm.2399

20. Frijns CJ, Kappelle LJ. Inflammatory cell adhesion molecules in ischemic cerebrovascular disease. Stroke (2002) 33(8):2115-22. doi:10.1161/01. STR.0000021902.33129.69

21. Ishikawa M, Zhang JH, Nanda A, Granger DN. Inflammatory responses to ischemia and reperfusion in the cerebral microcirculation. Front Biosci (2004) 9:1339-47. doi:10.2741/1330

22. Zhang Q, Raoof M, Chen Y, Sumi Y, Sursal T, Junger W, et al. Circulating mitochondrial DAMPs cause inflammatory responses to injury. Nature (2010) 464(7285):104-7. doi:10.1038/nature08780

23. Ginhoux F, Lim S, Hoeffel G, Low D, Huber T. Origin and differentiation of microglia. Front Cell Neurosci (2013) 7:45. doi:10.3389/fncel.2013.00045

24. Bonaventura A, Liberale L, Vecchié A, Casula M, Carbone F, Dallegri F, et al. Update on inflammatory biomarkers and treatments in ischemic stroke. Int J Mol Sci (2016) 17(12):E1967. doi:10.3390/ijms17121967

25. Aloisi F. Immune function of microglia. Glia (2001) 36(2):165-79. doi:10.1002/glia.1106

26. Selenica ML, Alvarez JA, Nash KR, Lee DC, Cao C, Lin X, et al. Diverse activation of microglia by chemokine (C-C motif) ligand 2 overexpression in brain. J Neuroinflammation (2013) 10:86. doi:10.1186/1742-2094-10-86

27. Jin $\mathrm{R}$, Yang G, Li G. Inflammatory mechanisms in ischemic stroke: role of inflammatory cells. J Leukoc Biol (2010) 87(5):779-89. doi:10.1189/jlb. 1109766

28. Pun PB, Lu J, Moochhala S. Involvement of ROS in BBB dysfunction. Free Radic Res (2009) 43(4):348-64. doi:10.1080/10715760902751902

29. del Zoppo GJ, Milner R, Mabuchi T, Hung S, Wang X, Berg GI, et al. Microglial activation and matrix protease generation during focal cerebral ischemia. Stroke (2007) 38(2 Suppl):646-51. doi:10.1161/01.STR.0000254477.34231.cb

30. Christensen RN, Ha BK, Sun F, Bresnahan JC, Beattie MS. Kainate induces rapid redistribution of the actin cytoskeleton in ameboid microglia. J Neurosci Res (2006) 84(1):170-81. doi:10.1002/jnr.20865

31. Ishihara Y, Takemoto T, Itoh K, Ishida A, Yamazaki T. Dual role of superoxide dismutase 2 induced in activated microglia: oxidative stress tolerance and convergence of inflammatory responses. J Biol Chem (2015) 290(37): 22805-17. doi:10.1074/jbc.M115.659151

32. Davalos D, Grutzendler J, Yang G, Kim JV, Zuo Y, Jung S, et al. ATP mediates rapid microglial response to local brain injury in vivo. Nat Neurosci (2005) 8(6):752-8. doi:10.1038/nn1472

33. Cherry JD, Olschowka JA, O'Banion MK. Neuroinflammation and M2 microglia: the good, the bad, and the inflamed. J Neuroinflammation (2014) 11:98. doi:10.1186/1742-2094-11-98 
34. Breckwoldt MO, Chen JW, Stangenberg L, Aikawa E, Rodriguez E, Qiu S, et al. Tracking the inflammatory response in stroke in vivo by sensing the enzyme myeloperoxidase. Proc Natl Acad Sci U S A (2008) 105(47):18584-9. doi:10.1073/pnas.0803945105

35. Lalancette-Hébert M, Gowing G, Simard A, Weng YC, Kriz J. Selective ablation of proliferating microglial cells exacerbates ischemic injury in the brain. J Neurosci (2007) 27(10):2596-605. doi:10.1523/JNEUROSCI.5360-06.2007

36. Nilupul Perera M, Ma HK, Arakawa S, Howells DW, Markus R, Rowe CC, et al. Inflammation following stroke. JClin Neurosci (2006) 13(1):1-8. doi:10.1016/j.jocn.2005.07.005

37. Stoll G, Jander S, Schroeter M. Inflammation and glial responses in ischemic brain lesions. Prog Neurobiol (1998) 56(2):149-71. doi:10.1016/ S0301-0082(98)00034-3

38. Gelderblom M, Leypoldt F, Steinbach K, Behrens D, Choe CU, Siler DA, et al. Temporal and spatial dynamics of cerebral immune cell accumulation in stroke. Stroke (2009) 40(5):1849-57. doi:10.1161/STROKEAHA.108.534503

39. Clausen BH, Lambertsen KL, Babcock AA, Holm TH, Dagnaes-Hansen F, Finsen B. Interleukin-1beta and tumor necrosis factor-alpha are expressed by different subsets of microglia and macrophages after ischemic stroke in mice. J Neuroinflammation (2008) 5:46. doi:10.1186/1742-2094-5-46

40. Kreutzberg GW. Microglia: a sensor for pathological events in the CNS. Trends Neurosci (1996) 19(8):312-8. doi:10.1016/0166-2236(96)10049-7

41. Streit WJ. Microglia as neuroprotective, immunocompetent cells of the CNS. Glia (2002) 40(2):133-9. doi:10.1002/glia.10154

42. Nakajima K, Kohsaka S. Microglia: neuroprotective and neurotrophic cells in the central nervous system. Curr Drug Targets Cardiovasc Haematol Disord (2004) 4(1):65-84. doi:10.2174/1568006043481284

43. Neumann J, Gunzer M, Gutzeit HO, Ullrich O, Reymann KG, Dinkel K. Microglia provide neuroprotection after ischemia. FASEB J (2006) 20(6):714-6. doi:10.1096/fj.05-4882fje

44. Banati RB, Gehrmann J, Schubert P, Kreutzberg GW. Cytotoxicity of microglia. Glia (1993) 7(1):111-8. doi:10.1002/glia.440070117

45. Perego C, Fumagalli S, De Simoni MG. Three-dimensional confocal analysis of microglia/macrophage markers of polarization in experimental brain injury. J Vis Exp (2013) 79:e50605. doi:10.3791/50605

46. Villalta SA, Nguyen HX, Deng B, Gotoh T, Tidball JG. Shifts in macrophage phenotypes and macrophage competition for arginine metabolism affect the severity of muscle pathology in muscular dystrophy. Hum Mol Genet (2009) 18(3):482-96. doi:10.1093/hmg/ddn376

47. Nathan CF, Murray HW, Wiebe ME, Rubin BY. Identification of interferongamma as the lymphokine that activates human macrophage oxidative metabolism and antimicrobial activity. J Exp Med (1983) 158(3):670-89. doi:10.1084/jem.158.3.670

48. Stein M, Keshav S, Harris N, Gordon S. Interleukin 4 potently enhances murine macrophage mannose receptor activity: a marker of alternative immunologic macrophage activation. JExp Med (1992) 176(1):287-92. doi:10.1084/jem.176. 1.287

49. Arumugam TV, Granger DN, Mattson MP. Stroke and T-cells. Neuromolecular Med (2005) 7(3):229-42. doi:10.1385/NMM:7:3:229

50. Amantea D, Micieli G, Tassorelli C, Cuartero MI, Ballesteros I, Certo M, et al. Rational modulation of the innate immune system for neuroprotection in ischemic stroke. Front Neurosci (2015) 9:147. doi:10.3389/fnins.2015. 00147

51. Xiong X, Barreto GE, Xu L, Ouyang YB, Xie X, Giffard RG. Increased brain injury and worsened neurological outcome in interleukin-4 knockout mice after transient focal cerebral ischemia. Stroke (2011) 42(7):2026-32. doi:10.1161/STROKEAHA.110.593772

52. Lalancette-Hébert M, Swarup V, Beaulieu JM, Bohacek I, Abdelhamid E, Weng YC, et al. Galectin-3 is required for resident microglia activation and proliferation in response to ischemic injury. J Neurosci (2012) 32(30): 10383-95. doi:10.1523/JNEUROSCI.1498-12.2012

53. Pérez-de Puig I, Miró F, Salas-Perdomo A, Bonfill-Teixidor E, FerrerFerrer M, Márquez-Kisinousky L, et al. IL-10 deficiency exacerbates the brain inflammatory response to permanent ischemia without preventing resolution of the lesion. J Cereb Blood Flow Metab (2013) 33(12):1955-66. doi: $10.1038 /$ jcbfm.2013.155

54. Munder M, Eichmann K, Morán JM, Centeno F, Soler G, Modolell M. Th1/ Th2-regulated expression of arginase isoforms in murine macrophages and dendritic cells. J Immunol (1999) 163(7):3771-7.
55. Webster CM, Hokari M, McManus A, Tang XN, Ma H, Kacimi R, et al. Microglial P2Y12 deficiency/inhibition protects against brain ischemia. PLoS One (2013) 8(8):e70927. doi:10.1371/journal.pone.0070927

56. Lehnardt S. Innate immunity and neuroinflammation in the CNS: the role of microglia in toll-like receptor-mediated neuronal injury. Glia (2010) 58(3):253-63. doi:10.1002/glia.20928

57. Kawabori M, Kacimi R, Kauppinen T, Calosing C, Kim JY, Hsieh CL, et al. Triggering receptor expressed on myeloid cells 2 (TREM2) deficiency attenuates phagocytic activities of microglia and exacerbates ischemic damage in experimental stroke. JNeurosci (2015) 35(8):3384-96. doi:10.1523/ JNEUROSCI.2620-14.2015

58. Haraguchi K, Kawamoto A, Isami K, Maeda S, Kusano A, Asakura K, et al. TRPM2 contributes to inflammatory and neuropathic pain through the aggravation of pronociceptive inflammatory responses in mice. J Neurosci (2012) 32(11):3931-41. doi:10.1523/JNEUROSCI.4703-11.2012

59. Doens D, Fernández PL. Microglia receptors and their implications in the response to amyloid $\beta$ for Alzheimer's disease pathogenesis. J Neuroinflammation (2014) 11:48. doi:10.1186/1742-2094-11-48

60. Rotshenker S. The role of Galectin-3/MAC-2 in the activation of the innate-immune function of phagocytosis in microglia in injury and disease. J Mol Neurosci (2009) 39(1-2):99-103. doi:10.1007/s12031-009-9186-7

61. Kawabori M, Yenari MA. Inflammatory responses in brain ischemia. Curr Med Chem (2015) 22(10):1258-77. doi:10.2174/0929867322666150209154 036

62. Huang L, Wu ZB, Zhuge Q, Zheng W, Shao B, Wang B, et al. Glial scar formation occurs in the human brain after ischemic stroke. Int J Med Sci (2014) 11(4):344-8. doi:10.7150/ijms.8140

63. Nowicka D, Rogozinska K, Aleksy M, Witte OW, Skangiel-Kramska J. Spatiotemporal dynamics of astroglial and microglial responses after photothrombotic stroke in the rat brain. Acta Neurobiol Exp (Wars) (2008) 68(2):155-68.

64. Dong Y, Benveniste EN. Immune function of astrocytes. Glia (2001) 36(2):180-90. doi:10.1002/glia.1107

65. Okada S, Nakamura M, Katoh H, Miyao T, Shimazaki T, Ishii K, et al. Conditional ablation of Stat 3 or Socs 3 discloses a dual role for reactive astrocytes after spinal cord injury. Nat Med (2006) 12(7):829-34. doi:10.1038/ nm1425

66. Yilmaz G, Granger DN. Cell adhesion molecules and ischemic stroke. Neurol Res (2008) 30(8):783-93. doi:10.1179/174313208X341085

67. Kriz J. Inflammation in ischemic brain injury: timing is important. Crit Rev Neurobiol (2006) 18(1-2):145-57. doi:10.1615/CritRevNeurobiol.v18.i1-2.150

68. Zhang RL, Chopp M, Chen H, Garcia JH. Temporal profile of ischemic tissue damage, neutrophil response, and vascular plugging following permanent and transient $(2 \mathrm{H})$ middle cerebral artery occlusion in the rat. J Neurol Sci (1994) 125(1):3-10. doi:10.1016/0022-510X(94)90234-8

69. Gros A, Ollivier V, Ho-Tin-Noé B. Platelets in inflammation: regulation of leukocyte activities and vascular repair. Front Immunol (2015) 5:678. doi:10.3389/fimmu.2014.00678

70. Mori E, del Zoppo GJ, Chambers JD, Copeland BR, Arfors KE. Inhibition of polymorphonuclear leukocyte adherence suppresses no-reflow after focal cerebral ischemia in baboons. Stroke (1992) 23(5):712-8. doi:10.1161/01.STR.23.5.712

71. Davies CA, Loddick SA, Stroemer RP, Hunt J, Rothwell NJ. An integrated analysis of the progression of cell responses induced by permanent focal middle cerebral artery occlusion in the rat. Exp Neurol (1998) 154(1):199-212. doi:10.1006/exnr.1998.6891

72. Huang J, Upadhyay UM, Tamargo RJ. Inflammation in stroke and focal cerebral ischemia. Surg Neurol (2006) 66(3):232-45. doi:10.1016/j.surneu. 2005.12.028

73. Emerich DF, Dean RL III, Bartus RT. The role of leukocytes following cerebral ischemia: pathogenic variable or bystander reaction to emerging infarct? Exp Neurol (2002) 173(1):168-81. doi:10.1006/exnr.2001.7835

74. Perez-de-Puig I, Miró-Mur F, Ferrer-Ferrer M, Gelpi E, Pedragosa J, Justicia C, et al. Neutrophil recruitment to the brain in mouse and human ischemic stroke. Acta Neuropathol (2015) 129(2):239-57. doi:10.1007/ s00401-014-1381-0

75. Enzmann G, Mysiorek C, Gorina R, Cheng YJ, Ghavampour S, Hannocks MJ, et al. The neurovascular unit as a selective barrier to polymorphonuclear granulocyte $(\mathrm{PMN})$ infiltration into the brain after ischemic injury. Acta Neuropathol (2013) 125(3):395-412. doi:10.1007/s00401-012-1076-3 
76. Becker KJ. Anti-leukocyte antibodies: LeukArrest (Hu23F2G) and enlimomab (R6.5) in acute stroke. Curr Med Res Opin (2002) 18(Suppl 2):s18-22. doi:10.1185/030079902125000688

77. Jander S, Kraemer M, Schroeter M, Witte OW, Stoll G. Lymphocytic infiltration and expression of intercellular adhesion molecule-1 in photochemically induced ischemia of the rat cortex. J Cereb Blood Flow Metab (1995) 15(1):42-51. doi:10.1038/jcbfm. 1995.5

78. Shichita T, Sugiyama Y, Ooboshi H, Sugimori H, Nakagawa R, Takada I, et al. Pivotal role of cerebral interleukin-17-producing gammadeltaT cells in the delayed phase of ischemic brain injury. Nat Med (2009) 15(8):946-50. doi:10.1038/nm.1999

79. Yilmaz G, Arumugam TV, Stokes KY, Granger DN. Role of T lymphocytes and interferon-gamma in ischemic stroke. Circulation (2006) 113(17):2105-12. doi:10.1161/CIRCULATIONAHA.105.593046

80. Li GZ, Zhong D, Yang LM, Sun B, Zhong ZH, Yin YH, et al. Expression of interleukin-17 in ischemic brain tissue. Scand J Immunol (2005) 62(5):481-6. doi:10.1111/j.1365-3083.2005.01683.x

81. Saino O, Taguchi A, Nakagomi T, Nakano-Doi A, Kashiwamura S, Doe N, et al. Immunodeficiency reduces neural stem/progenitor cell apoptosis and enhances neurogenesis in the cerebral cortex after stroke. J Neurosci Res (2010) 88(11):2385-97. doi:10.1002/jnr.22410

82. Liesz A, Suri-Payer E, Veltkamp C, Doerr H, Sommer C, Rivest S, et al. Regulatory $\mathrm{T}$ cells are key cerebroprotective immunomodulators in acute experimental stroke. Nat Med (2009) 15(2):192-9. doi:10.1038/nm.1927

83. Na SY, Mracsko E, Liesz A, Hünig T, Veltkamp R. Amplification of regulatory T cells using a CD28 superagonist reduces brain damage after ischemic stroke in mice. Stroke (2015) 46(1):212-20. doi:10.1161/STROKEAHA.114.007756

84. Kleinschnitz C, Kraft P, Dreykluft A, Hagedorn I, Göbel K, Schuhmann MK, et al. Regulatory $\mathrm{T}$ cells are strong promoters of acute ischemic stroke in mice by inducing dysfunction of the cerebral microvasculature. Blood (2013) 121(4):679-91. doi:10.1182/blood-2012-04-426734

85. Mao L, Li P, Zhu W, Cai W, Liu Z, Wang Y, et al. Regulatory T cells ameliorate tissue plasminogen activator-induced brain haemorrhage after stroke. Brain (2017) 140(7):1914-31. doi:10.1093/brain/awx111

86. Ren X, Akiyoshi K, Dziennis S, Vandenbark AA, Herson PS, Hurn PD, et al. Regulatory B cells limit CNS inflammation and neurologic deficits in murine experimental stroke. J Neurosci (2011) 31(23):8556-63. doi:10.1523/ JNEUROSCI.1623-11.2011

87. Nadareishvili ZG, Li H, Wright V, Maric D, Warach S, Hallenbeck JM, et al. Elevated pro-inflammatory CD4 + CD28- lymphocytes and stroke recurrence and death. Neurology (2004) 63(8):1446-51. doi:10.1212/01. WNL.0000142260.61443.7C

88. Kim J, Song TJ, Park JH, Lee HS, Nam CM, Nam HS, et al. Different prognostic value of white blood cell subtypes in patients with acute cerebral infarction. Atherosclerosis (2012) 222(2):464-7. doi:10.1016/j. atherosclerosis.2012.02.042

89. Shapira L, Soskolne WA, Sela MN, Offenbacher S, Barak V. The secretion of PGE2, IL-1 beta, IL-6, and TNF alpha by adherent mononuclear cells from early onset periodontitis patients. J Periodontol (1994) 65(2):139-46. doi:10.1902/jop.1994.65.2.139

90. Sobowale OA, Parry-Jones AR, Smith CJ, Tyrrell PJ, Rothwell NJ, Allan SM. Interleukin-1 in stroke: from bench to bedside. Stroke (2016) 47(8):2160-7. doi:10.1161/STROKEAHA.115.010001

91. Herx LM, Yong VW. Interleukin-1 beta is required for the early evolution of reactive astrogliosis following CNS lesion. J Neuropathol Exp Neurol (2001) 60(10):961-71. doi:10.1093/jnen/60.10.961

92. Thornton P, Pinteaux E, Allan SM, Rothwell NJ. Matrix metalloproteinase-9 and urokinase plasminogen activator mediate interleukin-1-induced neurotoxicity. MolCellNeurosci (2008)37(1):135-42. doi:10.1016/j.mcn.2007.09.002

93. Boutin H, LeFeuvre RA, Horai R, Asano M, Iwakura Y, Rothwell NJ. Role of IL-1alpha and IL-1beta in ischemic brain damage. J Neurosci (2001) 21(15):5528-34.

94. Haqqani AS, Nesic M, Preston E, Baumann E, Kelly J, Stanimirovic D. Characterization of vascular protein expression patterns in cerebral ischemia/ reperfusion using laser capture microdissection and ICAT-nanoLC-MS/MS. FASEB J (2005) 19(13):1809-21. doi:10.1096/fj.05-3793com

95. Yamasaki Y, Matsuura N, Shozuhara H, Onodera H, Itoyama Y, Kogure K. Interleukin-1 as a pathogenetic mediator of ischemic brain damage in rats. Stroke (1995) 26(4):676-80. doi:10.1161/01.STR.26.4.676
96. Lambertsen KL, Biber K, Finsen B. Inflammatory cytokines in experimental and human stroke. JCereb Blood Flow Metab (2012) 32(9):1677-98. doi:10.1038/jcbfm.2012.88

97. Kim DH, Yoo SD, Chon J, Yun DH, Kim HS, Park HJ, et al. Interleukin-6 receptor polymorphisms contribute to the neurological status of Korean patients with ischemic stroke. J Korean Med Sci (2016) 31(3):430-4. doi:10.3346/jkms.2016.31.3.430

98. Jin XF, Wang DL, Zhou Y, Xiong H. Association between the interleukin6-174 G/C polymorphism and risk of ischemic stroke: a meta-analysis. Genet Mol Res (2015) 14(4):13076-83. doi:10.4238/2015.October.26.3

99. Clark WM, Rinker LG, Lessov NS, Hazel K, Hill JK, Stenzel-Poore M, et al. Lack of interleukin- 6 expression is not protective against focal central nervous system ischemia. Stroke (2000) 31(7):1715-20. doi:10.1161/01. STR.31.7.1715

100. Yamashita T, Sawamoto K, Suzuki S, Suzuki N, Adachi K, Kawase T, et al. Blockade of interleukin-6 signaling aggravates ischemic cerebral damage in mice: possible involvement of Stat 3 activation in the protection of neurons. JNeurochem (2005) 94(2):459-68. doi:10.1111/j.1471-4159.2005. 03227.x

101. Yang GY, Gong C, Qin Z, Ye W, Mao Y, Bertz AL. Inhibition of TNFalpha attenuates infarct volume and ICAM-1 expression in ischemic mouse brain. Neuroreport (1998) 9(9):2131-4. doi:10.1097/00001756-19980622000041

102. Bruce AJ, Boling W, Kindy MS, Peschon J, Kraemer PJ, Carpenter MK, et al. Altered neuronal and microglial responses to excitotoxic and ischemic brain injury in mice lacking TNF receptors. Nat Med (1996) 2(7):788-94. doi:10.1038/nm0796-788

103. Parameswaran N, Patial S. Tumor necrosis factor- $\alpha$ signaling in macrophages. Crit Rev Eukaryot Gene Expr (2010) 20(2):87-103. doi:10.1615/ CritRevEukarGeneExpr.v20.i2.10

104. Lai AY, Todd KG. Microglia in cerebral ischemia: molecular actions and interactions. Can J Physiol Pharmacol (2006) 84(1):49-59. doi:10.1139/ Y05-143

105. Pradillo JM, Romera C, Hurtado O, Cárdenas A, Moro MA, Leza JC, et al. TNFR1 upregulation mediates tolerance after brain ischemic preconditioning. JCereb Blood Flow Metab (2005) 25(2):193-203. doi:10.1038/ sj.jcbfm. 9600019

106. Sriram K, O'Callaghan JP. Divergent roles for tumor necrosis factor-alpha in the brain. J Neuroimmune Pharmacol (2007) 2(2):140-53. doi:10.1007/ s11481-007-9070-6

107. Kang Z, Altuntas CZ, Gulen MF, Liu C, Giltiay N, Qin H, et al. Astrocyterestricted ablation of interleukin-17-induced Act1-mediated signaling ameliorates autoimmune encephalomyelitis. Immunity (2010) 32(3):414-25. doi:10.1016/j.immuni.2010.03.004

108. Yago T, Nanke Y, Kawamoto M, Furuya T, Kobashigawa T, Kamatani N, et al. IL-23 induces human osteoclastogenesis via IL-17 in vitro, and anti-IL-23 antibody attenuates collagen-induced arthritis in rats. Arthritis Res Ther (2007) 9(5):R96. doi:10.1186/ar2297

109. Ooboshi H, Ibayashi S, Shichita T, Kumai Y, Takada J, Ago T, et al. Postischemic gene transfer of interleukin-10 protects against both focal and global brain ischemia. Circulation (2005) 111(7):913-9. doi:10.1161/01. CIR.0000155622.68580.DC

110. van Exel E, Gussekloo J, de Craen AJ, Bootsma-van der Wiel A, Frölich M, Westendorp RG. Inflammation and stroke: the Leiden 85-plus study. Stroke (2002) 33(4):1135-8. doi:10.1161/01.STR.0000014206.05597.9E

111. Li P, Gan Y, Sun BL, Zhang F, Lu B, Gao Y, et al. Adoptive regulatory T-cell therapy protects against cerebral ischemia. Ann Neurol (2013) 74(3):458-71. doi:10.1002/ana.23815

112. Flanders KC, Ren RF, Lippa CF. Transforming growth factor-betas in neurodegenerative disease. Prog Neurobiol (1998) 54(1):71-85. doi:10.1016/ S0301-0082(97)00066-X

113. Lu YZ, Lin CH, Cheng FC, Hsueh CM. Molecular mechanisms responsible for microglia-derived protection of Sprague-Dawley rat brain cells during in vitro ischemia. Neurosci Lett (2005) 373(2):159-64. doi:10.1016/j. neulet.2004.10.004

114. Ma M, Ma Y, Yi X, Guo R, Zhu W, Fan X, et al. Intranasal delivery of transforming growth factor-betal in mice after stroke reduces infarct volume and increases neurogenesis in the subventricular zone. BMC Neurosci (2008) 9:117. doi:10.1186/1471-2202-9-117 
115. Gadani SP, Cronk JC, Norris GT, Kipnis J. IL-4 in the brain: a cytokine to remember. J Immunol (2012) 189(9):4213-9. doi:10.4049/jimmunol. 1202246

116. Liu X, Liu J, Zhao S, Zhang H, Cai W, Cai M, et al. Interleukin-4 is essential for microglia/macrophage M2 polarization and long-term recovery after cerebral ischemia. Stroke (2016) 47(2):498-504. doi:10.1161/ STROKEAHA.115.012079

117. Lively S, Hutchings S, Schlichter LC. Molecular and cellular responses to interleukin-4 treatment in a rat model of transient ischemia. J Neuropathol Exp Neurol (2016) 75(11):1058-71. doi:10.1093/jnen/nlw081

118. Wery-Zennaro S, Letourneur M, David M, Bertoglio J, Pierre J. Binding of IL-4 to the IL-13Ralpha(1)/IL-4Ralpha receptor complex leads to STAT3 phosphorylation but not to its nuclear translocation. FEBS Lett (1999) 464(1-2):91-6. doi:10.1016/S0014-5793(99)01680-4

119. Bonecchi R, Facchetti F, Dusi S, Luini W, Lissandrini D, Simmelink M, et al. Induction of functional IL-8 receptors by IL-4 and IL-13 in human monocytes. J Immunol (2000) 164(7):3862-9. doi:10.4049/jimmunol.164.7.3862

120. Van Kampen C, Gauldie J, Collins SM. Proinflammatory properties of IL-4 in the intestinal microenvironment. Am J Physiol Gastrointest Liver Physiol (2005) 288(1):G111-7. doi:10.1152/ajpgi.00014.2004

121. Major J, Fletcher JE, Hamilton TA. IL-4 pretreatment selectively enhances cytokine and chemokine production in lipopolysaccharide-stimulated mouse peritoneal macrophages. JImmunol (2002) 168(5):2456-63. doi:10.4049/ jimmunol.168.5.2456

122. Kim JS, Gautam SC, Chopp M, Zaloga C, Jones ML, Ward PA, et al. Expression of monocyte chemoattractant protein-1 and macrophage inflammatory protein-1 after focal cerebral ischemia in the rat. JNeuroimmunol (1995) 56(2):127-34. doi:10.1016/0165-5728(94)00138-E

123. Tokami H, Ago T, Sugimori H, Kuroda J, Awano H, Suzuki K, et al. RANTES has a potential to play a neuroprotective role in an autocrine/paracrine manner after ischemic stroke. Brain Res (2013) 1517:122-32. doi:10.1016/j. brainres.2013.04.022

124. Shyu WC, Lin SZ, Yen PS, Su CY, Chen DC, Wang HJ, et al. Stromal cellderived factor-1 alpha promotes neuroprotection, angiogenesis, and mobilization/homing of bone marrow-derived cells in stroke rats. J Pharmacol Exp Ther (2008) 324(2):834-49. doi:10.1124/jpet.107.127746

125. Murdoch C, Finn A. Chemokine receptors and their role in inflammation and infectious diseases. Blood (2000) 95(10):3032-43.

126. Ruscher K, Kuric E, Liu Y, Walter HL, Issazadeh-Navikas S, Englund E, et al. Inhibition of CXCL12 signaling attenuates the postischemic immune response and improves functional recovery after stroke. J Cereb Blood Flow Metab (2013) 33(8):1225-34. doi:10.1038/jcbfm.2013.71

127. Huang J, Li Y, Tang Y, Tang G, Yang GY, Wang Y. CXCR4 antagonist AMD3100 protects blood-brain barrier integrity and reduces inflammatory response after focal ischemia in mice. Stroke (2013) 44(1):190-7. doi:10.1161/ STROKEAHA.112.670299

128. Liu Y, Wu XM, Luo QQ, Huang S, Yang QW, Wang FX, et al. CX3CL1/ CX3CR1-mediated microglia activation plays a detrimental role in ischemic mice brain via p38MAPK/PKC pathway. J Cereb Blood Flow Metab (2015) 35(10):1623-31. doi:10.1038/jcbfm.2015.97

129. Soriano SG, Amaravadi LS, Wang YF, Zhou H, Yu GX, Tonra JR, et al. Mice deficient in fractalkine are less susceptible to cerebral ischemiareperfusion injury. J Neuroimmunol (2002) 125(1-2):59-65. doi:10.1016/ S0165-5728(02)00033-4

130. Cipriani R, Villa P, Chece G, Lauro C, Paladini A, Micotti E, et al. CX3CL1 is neuroprotective in permanent focal cerebral ischemia in rodents. J Neurosci (2011) 31(45):16327-35. doi:10.1523/JNEUROSCI.3611-11.2011

131. Jiang L, Newman M, Saporta S, Chen N, Sanberg C, Sanberg PR, et al. MIPlalpha and MCP-1 induce migration of human umbilical cord blood cells in models of stroke. Curr Neurovasc Res (2008) 5(2):118-24. doi:10.2174/ 156720208784310259

132. Garau A, Bertini R, Colotta F, Casilli F, Bigini P, Cagnotto A, et al. Neuroprotection with the CXCL8 inhibitor repertaxin in transient brain ischemia. Cytokine (2005) 30(3):125-31. doi:10.1016/j.cyto.2004. 12.014

133. Victoria EC, de Brito Toscano EC, de Sousa Cardoso AC, da Silva DG, de Miranda AS, da Silva Barcelos L, et al. Knockdown of C-C chemokine receptor 5 (CCR5) is protective against cerebral ischemia and reperfusion injury. Curr Neurovasc Res (2017) 14(2):125-31. doi:10.2174/1567202614666170313113056
134. Fan Y, Xiong X, Zhang Y, Yan D, Jian Z, Xu B. MKEY, a peptide inhibitor of CXCL4-CCL5 heterodimer formation, protects against stroke in mice. J Am Heart Assoc (2016) 5(9):e003615. doi:10.1161/JAHA.116.003615

135. Yoshimoto T, Houkin K, Tada M, Abe H. Induction of cytokines, chemokines and adhesion molecule mRNA in a rat forebrain reperfusion model. Acta Neuropathol (1997) 93(2):154-8. doi:10.1007/s004010050596

136. Goussev AV, Zhang Z, Anderson DC, Chopp M. P-selectin antibody reduces hemorrhage and infarct volume resulting from MCA occlusion in the rat. J Neurol Sci (1998) 161(1):16-22. doi:10.1016/S0022-510X(98)00262-7

137. Huang J, Choudhri TF, Winfree CJ, McTaggart RA, Kiss S, Mocco J, et al. Postischemic cerebrovascular E-selectin expression mediates tissue injury in murine stroke. Stroke (2000) 31(12):3047-53. doi:10.1161/01.STR.31.12.3047

138. Smith CW. Leukocyte-endothelial cell interactions. Semin Hematol (1993) 30(4 Suppl 4):45-53; discussion 54-5.

139. Sharar SR, Winn RK, Harlan JM. The adhesion cascade and anti-adhesion therapy: an overview. Springer Semin Immunopathol (1995) 16(4):359-78. doi:10.1007/BF00196093

140. Kitagawa K, Matsumoto M, Mabuchi T, Yagita Y, Ohtsuki T, Hori M, et al. Deficiency of intercellular adhesion molecule 1 attenuates microcirculatory disturbance and infarction size in focal cerebral ischemia. J Cereb Blood Flow Metab (1998) 18(12):1336-45. doi:10.1097/00004647-199812000-00008

141. Zhang RL, Chopp M, Jiang N, Tang WX, Prostak J, Manning AM, et al. Anti-intercellular adhesion molecule-1 antibody reduces ischemic cell damage after transient but not permanent middle cerebral artery occlusion in the Wistar rat. Stroke (1995) 26(8):1438-43. doi:10.1161/01.STR.26.8.1438

142. Carlos TM, Harlan JM. Leukocyte-endothelial adhesion molecules. Blood (1994) 84(7):2068-101.

143. Liesz A, Zhou W, Mracskó É, Karcher S, Bauer H, Schwarting S, et al. Inhibition of lymphocyte trafficking shields the brain against deleterious neuroinflammation after stroke. Brain (2011) 134(Pt 3):704-20. doi:10.1093/ brain/awr008

144. Llovera G, Hofmann K, Roth S, Salas-Pérdomo A, Ferrer-Ferrer M, Perego C, et al. Results of a preclinical randomized controlled multicenter trial ( $\mathrm{pRCT}$ ): anti-CD49d treatment for acute brain ischemia. Sci Transl Med (2015) 7(299):299ra121. doi:10.1126/scitranslmed.aaa9853

145. del Zoppo GJ. Acute anti-inflammatory approaches to ischemic stroke. Ann N Y Acad Sci (2010) 1207:143-8. doi:10.1111/j.1749-6632.2010.05761.x

146. Kapoor C, Vaidya S, Wadhwan V, Hitesh, Kaur G, Pathak A. Seesaw of matrix metalloproteinases (MMPs). J Cancer Res Ther (2016) 12(1):28-35. doi:10.4103/0973-1482.157337

147. Chang JJ, Stanfill A, Pourmotabbed T. The role of matrix metalloproteinase polymorphisms in ischemic stroke. Int J Mol Sci (2016) 17(8):E1323. doi:10.3390/ijms 17081323

148. Parks WC, Wilson CL, López-Boado YS. Matrix metalloproteinases as modulators of inflammation and innate immunity. Nat Rev Immunol (2004) 4(8):617-29. doi:10.1038/nri1418

149. McQuibban GA, Gong JH, Wong JP, Wallace JL, Clark-Lewis I, Overall CM. Matrix metalloproteinase processing of monocyte chemoattractant proteins generates CC chemokine receptor antagonists with anti-inflammatory properties in vivo. Blood (2002) 100(4):1160-7.

150. Lin R, Yu K, Li X, Tao J, Lin Y, Zhao C, et al. Electroacupuncture ameliorates post-stroke learning and memory through minimizing ultrastructural brain damage and inhibiting the expression of MMP-2 and MMP-9 in cerebral ischemia-reperfusion injured rats. Mol Med Rep (2016) 14(1):225-33. doi:10.3892/mmr.2016.5227

151. Turner RJ, Sharp FR. Implications of MMP9 for blood brain barrier disruption and hemorrhagic transformation following ischemic stroke. Front Cell Neurosci (2016) 10:56. doi:10.3389/fncel.2016.00056

152. Asahi M, Asahi K, Jung JC, del Zoppo GJ, Fini ME, Lo EH. Role for matrix metalloproteinase 9 after focal cerebral ischemia: effects of gene knockout and enzyme inhibition with BB-94. J Cereb Blood Flow Metab (2000) 20(12):1681-9. doi:10.1097/00004647-200012000-00007

153. Gidday JM, Gasche YG, Copin JC, Shah AR, Perez RS, Shapiro SD, et al. Leukocyte-derived matrix metalloproteinase- 9 mediates blood-brain barrier breakdown and is proinflammatory after transient focal cerebral ischemia. Am JPhysiol Heart Circ Physiol (2005) 289(2):H558-68. doi:10.1152/ ajpheart.01275.2004

154. Montaner J, Alvarez-Sabín J, Molina CA, Anglés A, Abilleira S, Arenillas J, et al. Matrix metalloproteinase expression is related to hemorrhagic transfor- 
mation after cardioembolic stroke. Stroke (2001) 32(12):2762-7. doi:10.1161/ 01.STR.32.8.1759

155. Asahi M, Sumii T, Fini ME, Itohara S, Lo EH. Matrix metalloproteinase 2 gene knockout has no effect on acute brain injury after focal ischemia. Neuroreport (2001) 12(13):3003-7. doi:10.1097/00001756-200109170-00050

156. Lucivero V, Prontera M, Mezzapesa DM, Petruzzellis M, Sancilio M, Tinelli A, et al. Different roles of matrix metalloproteinases-2 and -9 after human ischaemic stroke. Neurol Sci (2007) 28(4):165-70. doi:10.1007/s10072007-0814-0

157. Stuehr DJ, Griffith OW. Mammalian nitric oxide synthases. Adv Enzymol Relat Areas Mol Biol (1992) 65:287-346.

158. Toda N, Ayajiki K, Okamura T. Cerebral blood flow regulation by nitric oxide: recent advances. Pharmacol Rev (2009) 61(1):62-97. doi:10.1124/ pr.108.000547

159. Garry PS, Ezra M, Rowland MJ, Westbrook J, Pattinson KT. The role of the nitric oxide pathway in brain injury and its treatment - from bench to bedside. Exp Neurol (2015) 263:235-43. doi:10.1016/j.expneurol.2014.10.017

160. Iadecola $C$, Zhang F, Xu X. Inhibition of inducible nitric oxide synthase ameliorates cerebral ischemic damage. Am J Physiol (1995) 268(1 Pt 2):R286-92.

161. Zhao X, Haensel C, Araki E, Ross ME, Iadecola C. Gene-dosing effect and persistence of reduction in ischemic brain injury in mice lacking inducible nitric oxide synthase. Brain Res (2000) 872(1-2):215-8. doi:10.1016/ S0006-8993(00)02459-8

162. Tisdall MM, Rejdak K, Kitchen ND, Smith M, Petzold A. The prognostic value of brain extracellular fluid nitric oxide metabolites after traumatic brain injury. Neurocrit Care (2013) 19(1):65-8. doi:10.1007/s12028-011-9633-5

163. Carbone F, Teixeira PC, Braunersreuther V, Mach F, Vuilleumier N, Montecucco F. Pathophysiology and treatments of oxidative injury in ischemic stroke: focus on the phagocytic NADPH oxidase 2. Antioxid Redox Signal (2015) 23(5):460-89. doi:10.1089/ars.2013.5778

164. Wang $\mathrm{Q}$, Tang XN, Yenari MA. The inflammatory response in stroke. J Neuroimmunol (2007) 184(1-2):53-68. doi:10.1016/j.jneuroim.2006.11.014

165. Nauseef WM. Biological roles for the NOX family NADPH oxidases. J Biol Chem (2008) 283(25):16961-5. doi:10.1074/jbc.R700045200

166. Douglas G, Bendall JK, Crabtree MJ, Tatham AL, Carter EE, Hale AB, et al. Endothelial-specific Nox2 overexpression increases vascular superoxide and macrophage recruitment in ApoE?? mice. Cardiovasc Res (2012) 94(1):20-9. doi: $10.1093 / \mathrm{cvr} / \mathrm{cvs} 026$

167. Radermacher KA, Wingler K, Langhauser F, Altenhöfer S, Kleikers P, Hermans JJ, et al. Neuroprotection after stroke by targeting NOX4 as a source of oxidative stress. Antioxid Redox Signal (2013) 18(12):1418-27. doi:10.1089/ars.2012.4797

168. Dohi K, Ohtaki H, Nakamachi T, Yofu S, Satoh K, Miyamoto K, et al. Gp91phox (NOX2) in classically activated microglia exacerbates traumatic brain injury. J Neuroinflammation (2010) 7:41. doi:10.1186/1742-2094-7-41

169. Tang XN, Cairns B, Kim JY, Yenari MA. NADPH oxidase in stroke and cerebrovascular disease. Neurol Res (2012) 34(4):338-45. doi:10.1179/1743 132812 Y.0000000021

170. Kleinschnitz C, Grund H, Wingler K, Armitage ME, Jones E, Mittal M, et al. Post-stroke inhibition of induced NADPH oxidase type 4 prevents oxidative stress and neurodegeneration. PLoS Biol (2010) 8(9):e1000479. doi:10.1371/ journal.pbio.1000479

171. Baeuerle PA, Henkel T. Function and activation of NF-kappa B in the immune system. Annu Rev Immunol (1994) 12:141-79. doi:10.1146/annurev. iy.12.040194.001041

172. Schneider A, Martin-Villalba A, Weih F, Vogel J, Wirth T, Schwaninger M. NF-kappaB is activated and promotes cell death in focal cerebral ischemia. Nat Med (1999) 5(5):554-9. doi:10.1038/8432

173. Herrmann O, Baumann B, de Lorenzi R, Muhammad S, Zhang W, Kleesiek J, et al. IKK mediates ischemia-induced neuronal death. Nat Med (2005) 11(12):1322-9. doi:10.1038/nm1323

174. Ferrer I, Friguls B, Dalfó E, Planas AM. Early modifications in the expression of mitogen-activated protein kinase (MAPK/ERK), stress-activated kinases SAPK/JNK and p38, and their phosphorylated substrates following focal cerebral ischemia. Acta Neuropathol (2003) 105(5):425-37. doi:10.1007/ s00401-002-0661-2

175. Roy Choudhury G, Ryou MG, Poteet E, Wen Y, He R, Sun F, et al. Involvement of p38 MAPK in reactive astrogliosis induced by ischemic stroke. Brain Res (2014) 1551:45-58. doi:10.1016/j.brainres.2014.01.013
176. Chwang WB, O’Riordan KJ, Levenson JM, Sweatt JD. ERK/MAPK regulates hippocampal histone phosphorylation following contextual fear conditioning. Learn Mem (2006) 13(3):322-8. doi:10.1101/lm.152906

177. Qi SH, Hao LY, Yue J, Zong YY, Zhang GY. Exogenous nitric oxide negatively regulates the S-nitrosylation p38 mitogen-activated protein kinase activation during cerebral ischaemia and reperfusion. Neuropathol Appl Neurobiol (2013) 39(3):284-97. doi:10.1111/j.1365-2990.2012.01284.x

178. Alawieh A, Tomlinson S. Injury site-specific targeting of complement inhibitors for treating stroke. Immunol Rev (2016) 274(1):270-80. doi:10.1111/ imr.12470

179. Orsini F, Chrysanthou E, Dudler T, Cummings WJ, Takahashi M, Fujita T, et al. Mannan binding lectin-associated serine protease-2 (MASP-2) critically contributes to post-ischemic brain injury independent of MASP-1. J Neuroinflammation (2016) 13(1):213. doi:10.1186/s12974-016-0684-6

180. Orsini F, De Blasio D, Zangari R, Zanier ER, De Simoni MG. Versatility of the complement system in neuroinflammation, neurodegeneration and brain homeostasis. Front Cell Neurosci (2014) 8:380. doi:10.3389/ fncel.2014.00380

181. Song D, Sulewski ME Jr, Wang C, Song J, Bhuyan R, Sterling J, et al. Complement C5a receptor knockout has diminished light-induced microglia/ macrophage retinal migration. Mol Vis (2017) 23:210-8.

182. Elvington A, Atkinson C, Kulik L, Zhu H, Yu J, Kindy MS, et al. Pathogenic natural antibodies propagate cerebral injury following ischemic stroke in mice. J Immunol (2012) 188(3):1460-8. doi:10.4049/jimmunol.1102132

183. Orsini F, Villa P, Parrella S, Zangari R, Zanier ER, Gesuete R, et al. Targeting mannose-binding lectin confers long-lasting protection with a surprisingly wide therapeutic window in cerebral ischemia. Circulation (2012) 126(12):1484-94. doi:10.1161/CIRCULATIONAHA.112.103051

184. Kapetanovic R, Bokil NJ, Sweet MJ. Innate immune perturbations, accumulating DAMPs and inflammasome dysregulation: a ticking time bomb in ageing. Ageing Res Rev (2015) 24(Pt A):40-53. doi:10.1016/j.arr.2015.02.005

185. Marsh BJ, Williams-Karnesky RL, Stenzel-Poore MP. Toll-like receptor signaling in endogenous neuroprotection and stroke. Neuroscience (2009) 158(3):1007-20. doi:10.1016/j.neuroscience.2008.07.067

186. Yao H, Felfly H, Wang J, Zhou D, Haddad GG. DIDS protects against neuronal injury by blocking toll-like receptor 2 activated-mechanisms. J Neurochem (2009) 108(3):835-46. doi:10.1111/j.1471-4159.2008.05838.x

187. Caso JR, Pradillo JM, Hurtado O, Lorenzo P, Moro MA, Lizasoain I. Toll-like receptor 4 is involved in brain damage and inflammation after experimental stroke. Circulation (2007) 115(12):1599-608. doi:10.1161/ CIRCULATIONAHA.106.603431

188. Hua F, Ma J, Ha T, Kelley JL, Kao RL, Schweitzer JB, et al. Differential roles of TLR2 and TLR4 in acute focal cerebral ischemia/reperfusion injury in mice. Brain Res (2009) 1262:100-8. doi:10.1016/j.brainres.2009.01.018

189. Shichita T, Hasegawa E, Kimura A, Morita R, Sakaguchi R, Takada I, et al. Peroxiredoxin family proteins are key initiators of post-ischemic inflammation in the brain. Nat Med (2012) 18(6):911-7. doi:10.1038/nm.2749

190. Haynes SE, Hollopeter G, Yang G, Kurpius D, Dailey ME, Gan WB, et al. The $\mathrm{P} 2 \mathrm{Y} 12$ receptor regulates microglial activation by extracellular nucleotides. Nat Neurosci (2006) 9(12):1512-9. doi:10.1038/nn1805

191. Koizumi S, Shigemoto-Mogami Y, Nasu-Tada K, Shinozaki Y, Ohsawa K, Tsuda M, et al. UDP acting at P2Y6 receptors is a mediator of microglial phagocytosis. Nature (2007) 446(7139):1091-5. doi:10.1038/nature05704

192. Thomas M, Le WD. Minocycline: neuroprotective mechanisms in Parkinson's disease.CurrPharmDes (2004) 10(6):679-86. doi:10.2174/1381612043453162

193. Yrjänheikki J, Tikka T, Keinänen R, Goldsteins G, Chan PH, Koistinaho J. A tetracycline derivative, minocycline, reduces inflammation and protects against focal cerebral ischemia with a wide therapeutic window. Proc Natl Acad Sci U S A (1999) 96(23):13496-500. doi:10.1073/pnas.96.23.13496

194. Fox C, Dingman A, Derugin N, Wendland MF, Manabat C, Ji S, et al. Minocycline confers early but transient protection in the immature brain following focal cerebral ischemia-reperfusion. JCereb Blood Flow Metab (2005) 25(9):1138-49. doi:10.1038/sj.jcbfm.9600121

195. Machado LS, Kozak A, Ergul A, Hess DC, Borlongan CV, Fagan SC. Delayed minocycline inhibits ischemia-activated matrix metalloproteinases 2 and 9 after experimental stroke. BMC Neurosci (2006) 7:56. doi:10.1186/ 1471-2202-7-56

196. Chu LS, Fang SH, Zhou Y, Yu GL, Wang ML, Zhang WP, et al. Minocycline inhibits 5-lipoxygenase activation and brain inflammation after focal cerebral 
ischemia in rats. Acta Pharmacol Sin (2007) 28(6):763-72. doi:10.1111/ j.1745-7254.2007.00578.x

197. Yang Y, Salayandia VM, Thompson JF, Yang LY, Estrada EY, Yang Y. Attenuation of acute stroke injury in rat brain by minocycline promotes blood-brain barrier remodeling and alternative microglia/macrophage activation during recovery. J Neuroinflammation (2015) 12:26. doi:10.1186/ s12974-015-0245-4

198. Liu Z, Fan Y, Won SJ, Neumann M, Hu D, Zhou L, et al. Chronic treatment with minocycline preserves adult new neurons and reduces functional impairment after focal cerebral ischemia. Stroke (2007) 38(1):146-52. doi:10.1161/01.STR.0000251791.64910.cd

199. Jin Z, Liang J, Wang J, Kolattukudy PE. MCP-induced protein 1 mediates the minocycline-induced neuroprotection against cerebral ischemia/reperfusion injury in vitro and in vivo. J Neuroinflammation (2015) 12:39. doi:10.1186/ s12974-015-0264-1

200. Bhatt LK, Addepalli V. Potentiation of aspirin-induced cerebroprotection by minocycline: a therapeutic approach to attenuate exacerbation of transient focal cerebral ischaemia. Diab Vasc Dis Res (2012) 9(1):25-34. doi:10.1177/1479164111427753

201. Sakata H, Niizuma K, Yoshioka H, Kim GS, Jung JE, Katsu M, et al. Minocycline-preconditioned neural stem cells enhance neuroprotection after ischemic stroke in rats. J Neurosci (2012) 32(10):3462-73. doi:10.1523/ JNEUROSCI.5686-11.2012

202. Jin X, Liu J, Liu KJ, Rosenberg GA, Yang Y, Liu W. Normobaric hyperoxia combined with minocycline provides greater neuroprotection than either alone in transient focal cerebral ischemia. Exp Neurol (2013) 240:9-16. doi:10.1016/j.expneurol.2012.11.018

203. Lampl Y, Boaz M, Gilad R, Lorberboym M, Dabby R, Rapoport A, et al. Minocycline treatment in acute stroke: an open-label, evaluatorblinded study. Neurology (2007) 69(14):1404-10. doi:10.1212/01.wnl. 0000277487.04281.db

204. Switzer JA, Hess DC, Ergul A, Waller JL, Machado LS, Portik-Dobos V, et al. Matrix metalloproteinase-9 in an exploratory trial of intravenous minocycline for acute ischemic stroke. Stroke (2011) 42(9):2633-5. doi:10.1161/ STROKEAHA.111.618215

205. Yenari MA, Kunis D, Sun GH, Onley D, Watson L, Turner S, et al. Hu23F2G, an antibody recognizing the leukocyte $\mathrm{CD} 11 / \mathrm{CD} 18$ integrin, reduces injury in a rabbit model of transient focal cerebral ischemia. Exp Neurol (1998) 153(2):223-33. doi:10.1006/exnr.1998.6876

206. Krams M, Lees KR, Hacke W, Grieve AP, Orgogozo JM, Ford GA, et al. Acute stroke therapy by inhibition of neutrophils (ASTIN): an adaptive dose-response study of UK-279,276 in acute ischemic stroke. Stroke (2003) 34(11):2543-8. doi:10.1161/01.STR.0000092527.33910.89

207. Enlimomab Acute Stroke Trial Investigators. Use of anti-ICAM-1 therapy in ischemic stroke: results of the enlimomab acute stroke trial. Neurology (2001) 57(8):1428-34. doi:10.1212/WNL.57.8.1428

208. Schneider D, Berrouschot J, Brandt T, Hacke W, Ferbert A, Norris SH, et al. Safety, pharmacokinetics and biological activity of enlimomab (anti-ICAM-1 antibody): an open-label, dose escalation study in patients hospitalized for acute stroke. Eur Neurol (1998) 40(2):78-83. doi:10.1159/000007962

209. Emsley HC, Smith CJ, Georgiou RF, Vail A, Hopkins SJ, Rothwell NJ, et al. A randomised phase II study of interleukin-1 receptor antagonist in acute stroke patients. J Neurol Neurosurg Psychiatry (2005) 76(10):1366-72. doi:10.1136/jnnp.2004.054882

210. Fujiwara N, Som AT, Pham LD, Lee BJ, Mandeville ET, Lo EH, et al. A free radical scavenger edaravone suppresses systemic inflammatory responses in a rat transient focal ischemia model. Neurosci Lett (2016) 633:7-13. doi:10.1016/j.neulet.2016.08.048

211. Okamura K, Tsubokawa T, Johshita H, Miyazaki H, Shiokawa Y. Edaravone, a free radical scavenger, attenuates cerebral infarction and hemorrhagic infarction in rats with hyperglycemia. Neurol Res (2014) 36(1):65-9. doi:10. 1179/1743132813Y.0000000259

212. Edaravone Acute Infarction Study Group. Effect of a novel free radical scavenger, edaravone (MCI-186), on acute brain infarction. Randomized, placebo-controlled, double-blind study at multicenters. Cerebrovasc Dis (2003) 15(3):222-9. doi:10.1159/000069318

213. Wu HY, Tang Y, Gao LY, Sun WX, Hua Y, Yang SB, et al. The synergetic effect of edaravone and borneol in the rat model of ischemic stroke. Eur J Pharmacol (2014) 740:522-31. doi:10.1016/j.ejphar.2014.06.035
214. Yamaguchi T, Awano H, Matsuda H, Tanahashi N; PROTECT4.5 Investigators. Edaravone with and without. $6 \mathrm{Mg} / \mathrm{Kg}$ alteplase within 4.5 hours after ischemic stroke: a prospective cohort study (PROTECT4.5). J Stroke Cerebrovasc Dis (2017) 26(4):756-65. doi:10.1016/j.jstrokecerebrovasdis.2016.10.011

215. Aoki J, Kimura K, Morita N, Harada M, Metoki N, Tateishi Y, et al. YAMATO study (tissue-type plasminogen activator and edaravone combination therapy). Stroke (2017) 48(3):712-9. doi:10.1161/STROKEAHA.116.015042

216. Miyaji Y, Yoshimura S, Sakai N, Yamagami H, Egashira Y, Shirakawa M, et al. Effect of edaravone on favorable outcome in patients with acute cerebral large vessel occlusion: subanalysis of RESCUE-Japan registry. Neurol Med Chir (Tokyo) (2015) 55(3):241-7. doi:10.2176/nmc.ra.2014-0219

217. García-Bonilla L, Campos M, Giralt D, Salat D, Chacón P, HernándezGuillamon M, et al. Evidence for the efficacy of statins in animal stroke models: a meta-analysis. J Neurochem (2012) 122(2):233-43. doi:10.1111/ j.1471-4159.2012.07773.x

218. Ma M, Uekawa K, Hasegawa Y, Nakagawa T, Katayama T, Sueta D, et al. Pretreatment with rosuvastatin protects against focal cerebral ischemia/ reperfusion injury in rats through attenuation of oxidative stress and inflammation. Brain Res (2013) 1519:87-94. doi:10.1016/j.brainres.2013. 04.040

219. El-Sahar AE, Safar MM, Zaki HF, Attia AS, Ain-Shoka AA. Neuroprotective effects of pioglitazone against transient cerebral ischemic reperfusion injury in diabetic rats: modulation of antioxidant, anti-inflammatory, and anti-apoptotic biomarkers. Pharmacol Rep (2015) 67(5):901-6. doi:10.1016/j. pharep.2015.03.018

220. El-Sahar AE, Safar MM, Zaki HF, Attia AS, Ain-Shoka AA. Sitagliptin attenuates transient cerebral ischemia/reperfusion injury in diabetic rats: implication of the oxidative-inflammatory-apoptotic pathway. Life Sci (2015) 126:81-6. doi:10.1016/j.lfs.2015.01.030

221. Wei Y, Yemisci M, Kim HH, Yung LM, Shin HK, Hwang SK, et al. Fingolimod provides long-term protection in rodent models of cerebral ischemia. Ann Neurol (2011) 69(1):119-29. doi:10.1002/ana.22186

222. van Vuuren D, Marais E, Genade S, Lochner A. The differential effects of FTY720 on functional recovery and infarct size following myocardial ischaemia/reperfusion. Cardiovasc J Afr (2016) 27(6):375-86. doi:10.5830/ CVJA-2016-039

223. Liu J, Zhang C, Tao W, Liu M. Systematic review and meta-analysis of the efficacy of sphingosine-1-phosphate (S1P) receptor agonist FTY720 (fingolimod) in animal models of stroke. Int J Neurosci (2013) 123(3):163-9. doi:10. 3109/00207454.2012.749255

224. Campos F, Qin T, Castillo J, Seo JH, Arai K, Lo EH, et al. Fingolimod reduces hemorrhagic transformation associated with delayed tissue plasminogen activator treatment in a mouse thromboembolic model. Stroke (2013) 44(2):505-11. doi:10.1161/STROKEAHA.112.679043

225. Li W, Xu H, Testai FD. Mechanism of action and clinical potential of fingolimod for the treatment of stroke. Front Neurol (2016) 7:139. doi:10.3389/ fneur.2016.00139

226. Rolland WB, Lekic T, Krafft PR, Hasegawa Y, Altay O, Hartman R, et al. Fingolimod reduces cerebral lymphocyte infiltration in experimental models of rodent intracerebral hemorrhage. Exp Neurol (2013) 241:45-55. doi:10.1016/j.expneurol.2012.12.009

227. Colombo E, Di Dario M, Capitolo E, Chaabane L, Newcombe J, Martino G, et al. Fingolimod may support neuroprotection via blockade of astrocyte nitric oxide. Ann Neurol (2014) 76(3):325-37. doi:10.1002/ana.24217

228. Liesz A, Sun L, Zhou W, Schwarting S, Mracsko E, Zorn M, et al. FTY720 reduces post-ischemic brain lymphocyte influx but does not improve outcome in permanent murine cerebral ischemia. PLoS One (2011) 6(6):e21312. doi:10.1371/journal.pone.0021312

229. Kraft P, Göb E, Schuhmann MK, Göbel K, Deppermann C, Thielmann I, et al. FTY720 ameliorates acute ischemic stroke in mice by reducing thromboinflammation but not by direct neuroprotection. Stroke (2013) 44(11):320210. doi:10.1161/STROKEAHA.113.002880

230. Simats A, García-Berrocoso T, Montaner J. Natalizumab: a new therapy for acute ischemic stroke? Expert Rev Neurother (2016) 16(9):1013-21. doi:10. 1080/14737175.2016.1219252

231. Relton JK, Sloan KE, Frew EM, Whalley ET, Adams SP, Lobb RR. Inhibition of alpha4 integrin protects against transient focal cerebral ischemia in normotensive and hypertensive rats. Stroke (2001) 32(1):199-205. doi:10.1161/01. STR.32.1.199 
232. Elkins J, Veltkamp R, Montaner J, Johnston SC, Singhal AB, Becker K, et al. Safety and efficacy of natalizumab in patients with acute ischaemic stroke (ACTION): a randomised, placebo-controlled, double-blind phase 2 trial. Lancet Neurol (2017) 16(3):217-26. doi:10.1016/S1474-4422(16)30357-X

233. Yuen CM, Sun CK, Lin YC, Chang LT, Kao YH, Yen CH, et al. Combination of cyclosporine and erythropoietin improves brain infarct size and neurological function in rats after ischemic stroke. J Transl Med (2011) 9:141. doi:10.1186/1479-5876-9-141

234. Nighoghossian N, Berthezène Y, Mechtouff L, Derex L, Cho TH, Ritzenthaler T, et al. Cyclosporine in acute ischemic stroke. Neurology (2015) 84(22): 2216-23. doi:10.1212/WNL.0000000000001639

235. Kraft P, Göbel K, Meuth SG, Kleinschnitz C. Glatiramer acetate does not protect from acute ischemic stroke in mice. Exp Transl Stroke Med (2014) 6(1):4. doi:10.1186/2040-7378-6-4

236. Lok KZ, Basta M, Manzanero S, Arumugam TV. Intravenous immunoglobulin (IVIg) dampens neuronal toll-like receptor-mediated responses in ischemia. J Neuroinflammation (2015) 12:73. doi:10.1186/s12974-015-0294-8

237. Liu L, Yenari MA. Clinical application of therapeutic hypothermia in stroke. Neurol Res (2009) 31(4):331-5. doi:10.1179/174313209X444099

238. van der Worp HB, Sena ES, Donnan GA, Howells DW, Macleod MR. Hypothermia in animal models of acute ischaemic stroke: a systematic review and meta-analysis. Brain (2007) 130(Pt 12):3063-74. doi:10.1093/ brain/awm083

239. Yenari MA, Hemmen TM. Therapeutic hypothermia for brain ischemia: where have we come and where do we go? Stroke (2010) 41(10 Suppl):S72-4. doi:10.1161/STROKEAHA.110.595371

240. Yenari MA, Han HS. Neuroprotective mechanisms of hypothermia in brain ischaemia. Nat Rev Neurosci (2012) 13(4):267-78. doi:10.1038/nrn3174

241. Tahir RA, Pabaney AH. Therapeutic hypothermia and ischemic stroke: a literature review. Surg Neurol Int (2016) 7(Suppl 14):S381-6. doi:10.4103/2152-7806.183492

242. Klassman L. Therapeutic hypothermia in acute stroke. J Neurosci Nurs (2011) 43(2):94-103. doi:10.1097/JNN.0b013e31820b5fcd

243. Brogden RN, Speight TM, Avery GS. Minocycline: a review of its antibacterial and pharmacokinetic properties and therapeutic use. Drugs (1975) 9(4):251-91. doi:10.2165/00003495-197509040-00005

244. Cohen JA, Chun J. Mechanisms of fingolimod's efficacy and adverse effects in multiple sclerosis. Ann Neurol (2011) 69(5):759-77. doi:10.1002/ana.22426

245. Cai A, Schlunk F, Bohmann F, Kashefiolasl S, Brunkhorst R, Foerch C, et al. Coadministration of FTY720 and rt-PA in an experimental model of large hemispheric stroke-no influence on functional outcome and blood-brain barrier disruption. Exp Transl Stroke Med (2013) 5(1):11. doi:10.1186/2040-7378-5-11

246. Fu Y, Zhang N, Ren L, Yan Y, Sun N, Li YJ, et al. Impact of an immune modulator fingolimod on acute ischemic stroke. Proc Natl Acad Sci U S A (2014) 111(51):18315-20. doi:10.1073/pnas.1416166111

247. Hong JM, Lee JS, Song HJ, Jeong HS, Choi HA, Lee K. Therapeutic hypothermia after recanalization in patients with acute ischemic stroke. Stroke (2014) 45(1):134-40. doi:10.1161/STROKEAHA.113.003143

248. Tang XN, Liu L, Yenari MA. Combination therapy with hypothermia for treatment of cerebral ischemia. JNeurotrauma (2009) 26(3):325-31. doi:10.1089/neu.2008.0594

249. Tang XN, Liu L, Koike MA, Yenari MA. Mild hypothermia reduces tissue plasminogen activator-related hemorrhage and blood brain barrier disruption after experimental stroke. Ther Hypothermia Temp Manag (2013) 3(2):74-83. doi:10.1089/ther.2013.0010

250. Lyden P, Hemmen T, Grotta J, Rapp K, Ernstrom K, Rzesiewicz T, et al. Results of the ICTuS 2 trial (intravascular cooling in the treatment of stroke 2). Stroke (2016) 47(12):2888-95. doi:10.1161/STROKEAHA.116.014200

251. Kaste M, Murayama S, Ford GA, Dippel DW, Walters MR, Tatlisumak T, et al. Safety, tolerability and pharmacokinetics of MCI-186 in patients with acute ischemic stroke: new formulation and dosing regimen. Cerebrovasc Dis (2013) 36(3):196-204. doi:10.1159/000353680

252. Amarenco P, Bogousslavsky J, Callahan A III, Goldstein LB, Hennerici M, Rudolph AE, et al. High-dose atorvastatin after stroke or transient ischemic attack. N Engl J Med (2006) 355(6):549-59. doi:10.1056/NEJMoa061894

253. Endres M, Laufs U, Huang Z, Nakamura T, Huang P, Moskowitz MA, et al. Stroke protection by 3-hydroxy-3-methylglutaryl (HMG)-CoA reductase inhibitors mediated by endothelial nitric oxide synthase. Proc Natl Acad Sci U S A (1998) 95(15):8880-5. doi:10.1073/pnas.95.15.8880

254. van der Most PJ, Dolga AM, Nijholt IM, Luiten PG, Eisel UL. Statins: mechanisms of neuroprotection. Prog Neurobiol (2009) 88(1):64-75. doi:10.1016/j. pneurobio.2009.02.002

255. Collins R, Armitage J, Parish S, Sleight P, Peto R; Heart Protection Study Collaborative Group. Effects of cholesterol-lowering with simvastatin on stroke and other major vascular events in 20536 people with cerebrovascular disease or other high-risk conditions. Lancet (2004) 363(9411):757-67. doi:10.1016/S0140-6736(04)15690-0

256. Montaner J, Bustamante A, García-Matas S, Martínez-Zabaleta M, Jiménez C, de la Torre J, et al. Combination of thrombolysis and statins in acute stroke is safe: results of the STARS randomized trial (stroke treatment with acute reperfusion and simvastatin). Stroke (2016) 47(11):2870-3. doi:10.1161/ STROKEAHA.116.014600

257. Kumari R, Willing LB, Patel SD, Krady JK, Zavadoski WJ, Gibbs EM, et al. The PPAR-gamma agonist, darglitazone, restores acute inflammatory responses to cerebral hypoxia-ischemia in the diabetic ob/ob mouse. J Cereb Blood Flow Metab (2010) 30(2):352-60. doi:10.1038/jcbfm.2009.221

258. Bardelli C, Amoruso A, Federici Canova D, Fresu L, Balbo P, Neri T, et al. Autocrine activation of human monocyte/macrophages by monocytederived microparticles and modulation by PPAR $\gamma$ ligands. Br J Pharmacol (2012) 165(3):716-28. doi:10.1111/j.1476-5381.2011.01593.x

259. Dhib-Jalbut S. Mechanisms of action of interferons and glatiramer acetate in multiple sclerosis. Neurology (2002) 58(8 Suppl 4):S3-9. doi:10.1212/ WNL.58.8_suppl_4.S3

260. Machado LS, Sazonova IY, Kozak A, Wiley DC, El-Remessy AB, Ergul A, et al. Minocycline and tissue-type plasminogen activator for stroke: assessment of interaction potential. Stroke (2009) 40(9):3028-33. doi:10.1161/ STROKEAHA.109.556852

261. Fan X, Lo EH, Wang X. Effects of minocycline plus tissue plasminogen activator combination therapy after focal embolic stroke in type 1 diabetic rats. Stroke (2013) 44(3):745-52. doi:10.1161/STROKEAHA.111.000309

262. Kohler E, Prentice DA, Bates TR, Hankey GJ, Claxton A, van Heerden J, et al. Intravenous minocycline in acute stroke: a randomized, controlled pilot study and meta-analysis. Stroke (2013) 44(9):2493-9. doi:10.1161/ STROKEAHA.113.000780

263. Kanazawa M, Kawamura K, Takahashi T, Miura M, Tanaka Y, Koyama M, et al. Multiple therapeutic effects of progranulin on experimental acute ischaemic stroke. Brain (2015) 138(Pt 7):1932-48. doi:10.1093/brain/ awv079

264. dela Peña IC, Yoo A, Tajiri N, Acosta SA, Ji X, Kaneko Y, et al. Granulocyte colony-stimulating factor attenuates delayed tPA-induced hemorrhagic transformation in ischemic stroke rats by enhancing angiogenesis and vasculogenesis. J Cereb Blood Flow Metab (2015) 35(2):338-46. doi:10.1038/ jcbfm.2014.208

265. Zhu Z, Fu Y, Tian D, Sun N, Han W, Chang G, et al. Combination of the immune modulator fingolimod with alteplase in acute ischemic stroke: a pilot trial. Circulation (2015) 132(12):1104-12. doi:10.1161/ CIRCULATIONAHA.115.016371

266. Chen J, Liu L, Zhang H, Geng X, Jiao L, Li G, et al. Endovascular hypothermia in acute ischemic stroke: pilot study of selective intra-arterial cold saline infusion. Stroke (2016) 47(7):1933-5. doi:10.1161/STROKEAHA.116.012727

267. Lansberg MG, Bluhmki E, Thijs VN. Efficacy and safety of tissue plasminogen activator 3 to 4.5 hours after acute ischemic stroke: a metaanalysis. Stroke (2009) 40(7):2438-41. doi:10.1161/STROKEAHA.109.552547

268. Writing Group Members, Mozaffarian D, Benjamin EJ, Go AS, Arnett DK, Blaha MJ, et al. Heart disease and stroke statistics-2016 update: a report from the American Heart Association. Circulation (2016) 133(4):e38-360. doi:10.1161/CIR.0000000000000350

269. Kanazawa M, Takahashi T, Nishizawa M, Shimohata T. Therapeutic strategies to attenuate hemorrhagic transformation after tissue plasminogen activator treatment for acute ischemic stroke. J Atheroscler Thromb (2017) 24(3):240-53. doi:10.5551/jat.RV16006

270. Horn CM, Sun CH, Nogueira RG, Patel VN, Krishnan A, Glenn BA, et al. Endovascular reperfusion and cooling in cerebral acute ischemia (ReCCLAIMI).J NeurointervSurg(2014)6(2):91-5.doi:10.1136/neurintsurg2013-010656 
271. Palfree RG, Bennett HP, Bateman A. The evolution of the secreted regulatory protein progranulin. PLoS One (2015) 10(8):e0133749. doi:10.1371/journal. pone. 0133749

272. Abe K, Yamashita T, Takizawa S, Kuroda S, Kinouchi H, Kawahara N. Stem cell therapy for cerebral ischemia: from basic science to clinical applications. J Cereb Blood Flow Metab (2012) 32(7):1317-31. doi:10.1038/jcbfm. 2011.187

273. Ringelstein EB, Thijs V, Norrving B, Chamorro A, Aichner F, Grond M, et al. Granulocyte colony-stimulating factor in patients with acute ischemic stroke: results of the AX200 for ischemic stroke trial. Stroke (2013) 44(10):2681-7. doi:10.1161/STROKEAHA.113.001531

274. Mizuma A, Yamashita T, Kono S, Nakayama T, Baba Y, Itoh S, et al. Phase II trial of intravenous low-dose granulocyte colony-stimulating factor in acute ischemic stroke. J Stroke Cerebrovasc Dis (2016) 25(6):1451-7. doi:10.1016/j. jstrokecerebrovasdis.2016.01.022

275. Zlokovic BV, Griffin JH. Cytoprotective protein C pathways and implications for stroke and neurological disorders. Trends Neurosci (2011) 34(4):198-209. doi:10.1016/j.tins.2011.01.005
276. Amar AP, Griffin JH, Zlokovic BV. Combined neurothrombectomy or thrombolysis with adjunctive delivery of $3 \mathrm{~K} 3 \mathrm{~A}$-activated protein $\mathrm{C}$ in acute ischemic stroke. Front Cell Neurosci (2015) 9:344. doi:10.3389/fncel.2015. 00344

277. Asahi M, Huang Z, Thomas S, Yoshimura S, Sumii T, Mori T, et al. Protective effects of statins involving both eNOS and tPA in focal cerebral ischemia. J Cereb Blood Flow Metab (2005) 25(6):722-9. doi:10.1038/sj.jcbfm.9600070

Conflict of Interest Statement: The authors declare that the research was conducted in the absence of any commercial or financial relationships that could be construed as a potential conflict of interest.

Copyright (c) 2017 Mizuma and Yenari. This is an open-access article distributed under the terms of the Creative Commons Attribution License (CC BY). The use, distribution or reproduction in other forums is permitted, provided the original author(s) or licensor are credited and that the original publication in this journal is cited, in accordance with accepted academic practice. No use, distribution or reproduction is permitted which does not comply with these terms. 